TITLE:

\title{
Product carbon footprint and energy analysis of alternative coffee products in Japan
}

\section{$\operatorname{AUTHOR}(\mathrm{S})$ :}

Hassard, H.A.; Couch, M.H.; Techa-erawan, T.; McLellan, B.C.

\section{CITATION:}

Hassard, H.A....[et al]. Product carbon footprint and energy analysis of alternative coffee products in Japan. Journal of Cleaner Production 2014, 73: 310-321

ISSUE DATE:

2014-06-15

URL:

http://hdl.handle.net/2433/188888

\section{RIGHT:}

@ 2014 Elsevier Ltd.; この論文は出版社版でありません。引用の際には 出版社版をご確認ご利用ください。; This is not the published version. Please cite only the published version. 
Pre-print version. Please refer to the published version:

Hassard H.A., Couch M.H., Techa-Erawan T., Mclellan B.C.. Product carbon footprint and energy analysis of alternative coffee products in Japan. Journal of Cleaner Production. 73( ), 310-321 (2014) http://dx.doi.org/10.1016/i.jclepro.2014.02.006.

\title{
Product carbon footprint and energy analysis of alternative coffee products in Japan
}

\author{
H.A. Hassard, M.H. Couch, T. Techa-erawan, B.C. McLellan ${ }^{1}$
}

Graduate School of Energy Science, Kyoto University, Yoshida honmachi, Sakyo-ku, Kyoto 6068501, Japan.

\section{Abstract}

Coffee is an important global beverage, and has received significant attention especially in terms of the social and environmental sustainability of its production. This paper calculates the product carbon footprint (PCF) and conducts an analysis of energy usage for six alternative coffee products. The analysis shows that espresso coffee had the lowest impact $\left(0.13 \mathrm{kWh}\right.$ and $49 \mathrm{~g} \mathrm{CO}_{2}$ per serve), while canned coffee provided the highest impact ( $0.76 \mathrm{kWh}$ and $223 \mathrm{~g} \mathrm{CO}_{2}$ per serve). The latte had the second highest embodied energy impact, with $0.54 \mathrm{kWh}$ and the highest PCF of $224 \mathrm{~g} \mathrm{CO}_{2}$ per serve. On a per millilitre basis however, espresso coffee provided the highest impact $(0.0048 \mathrm{kWh} /$ $\mathrm{mL}$ and $0.8 \mathrm{~g} \mathrm{CO}_{2}-\mathrm{eq} / \mathrm{mL}$ ), followed by canned coffee and the latte. This indicates that care must be used in the selection of an appropriate functional unit, as the ranking of PCF can be overturned according to the basis of comparison. The highest contributing factors were the emissions from milk, packaging (for the can) and the production stages of the green coffee beans. Despite only holding around $17 \%$ of the market share of consumed coffee, the canned coffee product contributes around half of the national carbon footprint from coffee consumption. Current commercial incentives for consumers to use their own cups were compared to carbon taxation and found to value carbon approximately three orders of magnitude higher than carbon market rates.

Keywords: coffee; product carbon footprint; energy; greenhouse gas; lifecycle; Japan;

\section{Introduction}

With close to 7 million tonnes of green beans consumed per year (ICO, 2012), coffee is one of the top 20 most traded agricultural commodities worldwide (FAO, 2012). On average, over 2.25 billion serves of coffee are consumed in the world every day (Ponte, 2002). However, the significance of global coffee production extends beyond the large consumption numbers - the socioeconomic implications of its production in largely developing countries (Bacon, 2005; Danse and Wolters, 2003; Wilson, 2010), and the environmental burden due to fertiliser use, habitat

\footnotetext{
${ }^{1}$ Corresponding author contact details: E-mail: b-mclellan@energy.kyoto-u.ac.jp Tel.: +81 757539173 Fax: +81 757534775
} 
Pre-print version. Please refer to the published version:

Hassard H.A., Couch M.H., Techa-Erawan T., Mclellan B.C.. Product carbon footprint and energy analysis of alternative coffee products in Japan. Journal of Cleaner Production. 73( ), 310-321 (2014) http://dx.doi.org/10.1016/i.jclepro.2014.02.006.

destruction and effluent releases (Chanakya and De Alwis, 2004; Coltro et al., 2006) have been welldocumented.

Consumers are becoming increasingly interested in information regarding the impacts resulting from their purchases, especially in terms of climate change. As a result, product carbon footprints (PCFs) have emerged as a method for assessing greenhouse gas emissions from goods and services over their life cycle, with moves to create global standard methodologies (BSI, 2011) in an attempt to improve the quality and comparability of reported PCFs. Despite the focus on the socioenvironmental impacts of production, there have only been limited efforts to quantify and compare the energy and greenhouse gas emissions across the life cycle of coffee - notably Humbert, et al. (Humbert et al., 2009) and Tchibo (Tchibo, 2009). This paper examines the PCFs and energy use in a 'cradle-to-grave' analysis which ranges from cultivation to disposal of a selection of different coffee products available in the vicinity of Kyoto University's main campus in Kyoto, Japan.

With regard to end use, Japan ranks as the $4^{\text {th }}$ highest consumer of coffee in total, but approximately the $26^{\text {th }}$ highest per capita of the major importing and producing nations worldwide (ICO, 2012). In Japan, home to a culture that embraces convenience like no other, coffee is served in many forms and varieties. For the purpose of this study, we have examined the PCFs of the major available hot coffee products, namely: drip filter (multi-cup brewed coffee); espresso (and variations); single-cup filter bags (individually packaged); coffee press; instant; and canned. Based on surveyed consumption figures from the All Japan Coffee Association (AJCA, 2012), roasted coffee represented $54 \%$, instant $16 \%$ and canned coffee $21 \%$ of the total consumption of coffee (when converted to a green bean equivalent, GBE, using factors from the International Coffee Organisation, ICO (ICO, 2012)) while on a "number of serves" basis roasted coffee represented $30 \%$, instant $43 \%$ and canned $17 \%$. A number of notable omissions to the current examination are siphon coffee, iced coffee and ready-to-drink liquid coffee, which were excluded either because they are typically served cold or because their application is not as widespread as the selected products.

The most relevant previous work in this area has been the presentation of a life cycle assessment of instant, drip filter and capsule espresso coffee (Humbert et al., 2009) which indicated that instant coffee had the lowest life cycle impacts. The current study differentiates from this by including a number of other alternatives. Another study by Tchibo $\mathrm{GmbH}$ examined the PCF of a serve of espresso from a single source country (Tanzania) (Tchibo, 2009) which again presented a limited product scope, but makes a useful comparison for the results of this study. There have also been a number of studies focussed on single elements in the life cycle - such as packaging (Büsser and Jungbluth, 2009; De Monte et al., 2005), heat recovery from roasting (De Monte et al., 2003), and the balance of greenhouse gas emissions over the cultivation of coffee using different environmentally-based agricultural practices (shade grown coffee and organic coffee) (Hergoualc'h et al., 2012; Noponen et al., 2012). Specifically within Japan, the recently completed project to demonstrate PCFs as a lead-up to a proposed carbon footprint labelling scheme has produced two PCFs for instant coffee products (available only in Japanese) (JEMAI, 2012).

Thus, there is an apparent gap in knowledge regarding the combined picture of the multiple routes and stages in the production and consumption of coffee. This study follows the current best 
Pre-print version. Please refer to the published version:

Hassard H.A., Couch M.H., Techa-Erawan T., Mclellan B.C.. Product carbon footprint and energy analysis of alternative coffee products in Japan. Journal of Cleaner Production. 73( ), 310-321 (2014) http://dx.doi.org/10.1016/i.jclepro.2014.02.006.

available standard (PAS 2050: 2011) (BSI, 2011) and seeks to address most of the common routes to coffee that consumers (especially consumers in Japan) have available to them, which has not been accomplished in previous studies. The study further highlights a number of "hot spots" and presents some strategies for reducing the impact of these key stages through technology and input substitution as well as examining an existing carbon reduction incentive scheme to compare with carbon market prices.

\section{Methodology}

This study applies the publicly available specification (PAS 2050: 2011) (BSI, 2011) as the best available methodology for systematically assessing the PCF of alternative coffee products. Energy as well as greenhouse gas emissions have been assessed. Priority has been given to obtaining data from primary sources wherever possible, secondary sources with specificity to Japan as the second preference, followed by other secondary sources. Data has been obtained for the year 2010 as a basis wherever possible.

\subsection{Functional unit}

The functional unit used as a basis for comparison between product types is "one serve" of the respective hot coffee product. The serve of coffee product is thus variable in its volume and content of coffee liquor, dilution water, milk and other components. The justification behind the use of this non-standardised unit is that the actual purchasable product is in itself variable - for example, a regular sized latte is $230 \mathrm{~mL}$, while a straight espresso is around $30 \mathrm{~mL}$ and a can of coffee is $190 \mathrm{~mL}-$ these volumes do not experience significant variability, and the consumer is thus aware of these parameters in the purchase of the specific product. In order to examine the relative impacts, the results are also presented on a "per millilitre of beverage" and a "per gram of roast coffee" basis.

Data on the volume and mass of each ingredient (most notably coffee, milk and water) was obtained from the available product labels, by a survey of a café in the vicinity of Kyoto University, and through direct measurement.

\subsection{Scope and system boundaries}

This analysis applies to hot coffee products available on or in the vicinity of Kyoto University's main campus however the results are largely applicable to other locations. For the sake of clearer comparison, we have considered a standard mix of $20 \%$ Guatemalan and $80 \%$ Costa Rican coffee beans which is used in four of the products considered (can, drip, one-cup filter and espresso), and is potentially applicable to the other products.

The general system boundaries are shown in Figure 1. The first three stages are general across all types of coffee product examined (especially when considered that many companies are producing one or more of the alternative coffee products), whereas the final processes stages are differentiated between the different product types. While the title of some of the alternative stages may be similar, the specific operations involved are often different - e.g. disposal of a can is via 
Pre-print version. Please refer to the published version:

Hassard H.A., Couch M.H., Techa-Erawan T., Mclellan B.C.. Product carbon footprint and energy analysis of alternative coffee products in Japan. Journal of Cleaner Production. 73( ), 310-321 (2014) http://dx.doi.org/10.1016/i.jclepro.2014.02.006.

recycling, while disposal of a paper coffee cup is through incineration. In Figure 1 the additional interlinked life cycles for the production, processing and delivery of milk and packaging materials are not shown, but are included in the assessment as discussed later on.

The electricity mix for all activities undertaken in Japan, was assumed to be the mix stated by Kansai electric power company with a carbon intensity of $311 \mathrm{~g} \mathrm{CO}_{2}$-eq / kWh (KEPCO, 2011), although a sensitivity analysis was undertaken to identify the impacts of a potential non-nuclear Kansai region (which was the case for some months in 2012 and 2013).

\subsubsection{Production of green coffee beans for export}

Production of export-ready green coffee beans involves multiple processes, which are only briefly examined here. The major processes are shown in Figure 2.

The emissions estimates for farming and processing of the coffee cherries through to green beans ready for export were adapted from key literature sources that reflected the major location of production (specifically references (Castro-Tanzi et al., 2012; Hergoualc'h et al., 2012; Noponen et al., 2012) were useful identifying the use of fertiliser, as well as emissions and absorption of GHGs during coffee cultivation, while Adams and Ghaly's study (Adams and Ghaly, 2007) provided useful figures on energy for processing coffee).

We have assumed Guatemalan and Costa Rican coffee beans in a 1:4 ratio as the standard blend of beans due to this being the predominant mix utilised in by the retail coffee shop that assisted in the work (and similarly, the mix that the retail chain uses in their canned and one-cup drip filter coffee, as well as one blend they sell as roasted beans).Costa Rican figures have been particularly widely examined because of the country's stated aim of becoming carbon neutral by 2021 (Hergoualc'h et al., 2012). For the base blend, the Costa Rican data up to the domestic transportation stage are taken to be applicable for the entire blend. Export transportation is then included on the basis of Guatemala : Costa Rica blend ratio.

The cultivation, harvesting and treatment of the coffee cherries to obtain the initial green bean ready for export is considered to be undertaken in a similar manner for all of the coffee products. Cultivation considers the process of growing and maintaining the coffee plantation, while not including nursery operations. The major inputs to cultivation are fertiliser, for which the quantities and emissions are obtained from a previous study, which examined both conventional and organic coffee production under shade and non-shade conditions (Noponen et al., 2012). In their study, they assumed that the fertiliser and other agricultural treatments were transported $10 \mathrm{~km}$ to site(Noponen et al., 2012) and included the production of the fertiliser in the PCF. The study used a variety of emissions factors for comparison, of which we have utilised the IPCC global default factors. Harvesting of coffee cherries is estimated be done by hand in the base case, as this is indicated as being typical in many countries (Illy and Viani, 2005), although there has also been a move towards mechanisation (Adams and Ghaly, 2007). The emissions for processing of the cherries into dried, stored green coffee beans are taken from the study of Adams and Ghaly (Adams and Ghaly, 2007). In their study, they did not include the emissions due to waste treatment, which has been added in the current study (using default IPCC factors and assuming $80 \%$ removal of sludge in anaerobic waste 
Pre-print version. Please refer to the published version:

Hassard H.A., Couch M.H., Techa-Erawan T., Mclellan B.C.. Product carbon footprint and energy analysis of alternative coffee products in Japan. Journal of Cleaner Production. 73( ), 310-321 (2014) http://dx.doi.org/10.1016/i.jclepro.2014.02.006.

water settling ponds less than $2 \mathrm{~m}$ deep). The cleaning and grade separation, and bagging and container packaging are omitted due to lack of data, but this is considered to only have a minor impact on the overall PCF. The emissions factors derived or obtained directly from the literature are shown in Table 1.

Table 1: Emissions factors for the cultivation through processing stages of green coffee production

\begin{tabular}{|c|c|c|c|c|}
\hline $\begin{array}{l}\text { Process } \\
\text { stage }\end{array}$ & & $\begin{array}{l}\text { Energy (kWh / kg green } \\
\text { coffee) }\end{array}$ & $\begin{array}{l}\text { GHG (g CO } \text { CO }_{2} \text { / kg green } \\
\text { coffee) }\end{array}$ & Ref. \\
\hline \multirow[t]{2}{*}{ Cultivation } & Conventional & & $2,550-3,120$ & \multirow{2}{*}{$\begin{array}{l}\text { (Noponen } \\
\text { et al., } \\
2012 \text { ) }\end{array}$} \\
\hline & Organic & - & $1,410-1,900$ & \\
\hline Harvesting & By hand & 0 & 0 & $\begin{array}{l}\text { (Illy and } \\
\text { Viani, } \\
2005 \text { ) }\end{array}$ \\
\hline \multirow[t]{2}{*}{$\begin{array}{l}\text { Cherry } \\
\text { processing }\end{array}$} & $\begin{array}{l}\text { Wet } \\
\text { processing }\end{array}$ & $6.73-9.27$ & $40-60$ & $\begin{array}{l}\text { (Adams } \\
\text { and } \\
\text { Ghaly, } \\
\text { 2007) }\end{array}$ \\
\hline & Wastewater & - & 94 & $\begin{array}{l}\text { (Doorn et } \\
\text { al., 2006) }\end{array}$ \\
\hline $\begin{array}{l}\text { Drying and } \\
\text { storage }\end{array}$ & $\begin{array}{l}\text { Mechanical } \\
\text { drying }\end{array}$ & \multicolumn{2}{|c|}{ Combined with cherry processing } & $\begin{array}{l}\text { (Adams } \\
\text { and } \\
\text { Ghaly, } \\
\text { 2007) }\end{array}$ \\
\hline $\begin{array}{l}\text { Cleaning } \\
\text { and grade } \\
\text { separation }\end{array}$ & & \multicolumn{2}{|l|}{ Not included } & \\
\hline $\begin{array}{l}\text { Bagging } \\
\text { and } \\
\text { container } \\
\text { packaging }\end{array}$ & & \multicolumn{2}{|l|}{ Not included } & \\
\hline
\end{tabular}

For the current study, conventional inorganic, mono-culture, unshaded coffee farms are considered, under average to intense ranges of fertilisation as the base case. We have also compared the case of organic cultivation practices in the discussion. We have not considered the 
Pre-print version. Please refer to the published version:

Hassard H.A., Couch M.H., Techa-Erawan T., Mclellan B.C.. Product carbon footprint and energy analysis of alternative coffee products in Japan. Journal of Cleaner Production. 73( ), 310-321 (2014) http://dx.doi.org/10.1016/i.jclepro.2014.02.006.

effect of diverse species cropping or shade-grown cropping, although it may have a significant potential impact (Castro-Tanzi et al., 2012; Noponen et al., 2012). The most significant areas of impact due to these alternative cultivation methods are due to the uptake and storage of $\mathrm{CO}_{2}$ and the direct and indirect emissions of $\mathrm{N}_{2} \mathrm{O}$.

The cultivation of coffee - whether in shaded or unshaded plantations, has been shown to produce a net removal of $\mathrm{CO}_{2}$ absorbed in the non-product biomass of the coffee plants. In shaded plantations, this absorption is expected to be higher (Hergoualc'h et al., 2012). Using only the above ground phytomass quoted in the previous study (Hergoualc'h et al., 2012) for monoculture coffee (assumed not to include the coffee itself), and the average coffee yield of 1.5 tonnes / ha (Coltro et al., 2006), this is estimated to be equivalent to a removal of $2.97 \mathrm{~g} \mathrm{CO}_{2}$-eq / g green coffee. This removal has not been included in the base case PCF, as coffee plantations are grown over a 30 year period, which would mean that this storage would be released within the 100 year period applicable to emissions. However, we have also shown the impact of including this in the results and discussion.

\subsubsection{Transportation of green coffee beans}

Transportation of green coffee beans from Costa Rica and Guatemala to Japan was considered to be in bulk shipping containers, while the transportation to the port varied depending on the country. Emissions factors were estimated or used directly from those specified in the Japan carbon footprint product category rule for instant coffee (JEMAl, 2010) and distances of transport were estimated using an internet application (SeaRates.Com, 2011). The data utilised are shown in Table 1.

Table 2: Transport distances and emissions factors (EF) for the transportation of green coffee beans on a net tonnekilometre (ntk) basis

\begin{tabular}{lcccc}
\hline & Domestic transport & Domestic EF & International Transport & International EF \\
& $(\mathbf{k m})$ & $(\mathbf{k g ~ C O}$ - $\mathbf{e q} / \mathbf{n t k})$ & $\mathbf{( k m )}$ & $\mathbf{( k g ~ C O}$-eq / ntk) \\
\hline Guatemala & 200 & 0.149 & 12660 & 0.00907 \\
Costa Rica & 50 & 0.149 & 13488 & 0.00907 \\
\hline
\end{tabular}

Analysis of beans sourced from alternative countries was undertaken to examine the sensitivity to specific coffee blend. The alternative source countries are shown in Table 2 and represent some of the major imported coffee sources for Japan and among the largest producers of coffee globally (ICO, 2012). The overall emissions from source country domestic transport and international transport are shown in Figure 3. 
Pre-print version. Please refer to the published version:

Hassard H.A., Couch M.H., Techa-Erawan T., Mclellan B.C.. Product carbon footprint and energy analysis of alternative coffee products in Japan. Journal of Cleaner Production. 73( ), 310-321 (2014) http://dx.doi.org/10.1016/i.jclepro.2014.02.006.

Table 3: Transport distances and emissions factors (EF) for alternative import sources of green coffee beans on a net tonne-kilometre (ntk) basis

\begin{tabular}{|c|c|c|c|c|}
\hline & $\begin{array}{c}\text { Domestic transport } \\
(\mathrm{km})\end{array}$ & $\begin{array}{c}\text { Domestic EF } \\
\text { (kg CO}- \text {-eq / ntk) }\end{array}$ & $\begin{array}{l}\text { International Transport } \\
\text { (km) }\end{array}$ & $\begin{array}{l}\text { International EF } \\
\text { (kg CO} \text {-eq / ntk) }\end{array}$ \\
\hline Brazil & 750 & 0.158 & 22,900 & 0.00907 \\
\hline Vietnam & 300 & 0.158 & 4,300 & 0.00907 \\
\hline Indonesia & 200 & 0.134 & 5,600 & 0.00907 \\
\hline Colombia & 350 & 0.144 & 14,700 & 0.00907 \\
\hline India & 250 & 0.158 & 9,000 & 0.00907 \\
\hline Ethiopia & 650 & 0.150 & 12,200 & 0.00907 \\
\hline Tanzania & 350 & 0.149 & 12,700 & 0.00907 \\
\hline Ecuador & 250 & 0.145 & 15,000 & 0.00907 \\
\hline
\end{tabular}

As determined in the context of the entire PCF, the transportation of green beans contributed only a small percentage, therefore the comparison of alternative coffee sources was not undertaken any further. It is apparent that sourcing green coffee from Indonesia or Vietnam will reduce this impact over sourcing from Brazil, however the overall contribution is small. Alternative cultivation methods for obtaining the green beans would be a much more important contribution, and assuming alternative methods available in different countries, it would be valid to obtain beans from another producer as any benefit would be likely to outweigh any additional transportation impacts.

\subsubsection{Roasting}

Coffee roasting is considered to be undertaken in Japan - this is the actual route of the coffee products considered here, but also green bean trade is much larger than roasted or other coffee products due to the potential for spoiling or quality degradation if roasted in the exporting country. Green beans are roasted using very similar roasters at the commercial scale, with the major differences being in the capacity of the particular roaster. Roasting takes between 8 and 30 min depending on the level of roast desired, with the full cycle of a single batch typically involving up to 5 min cooling. In the current study, a dark roast, fairly typical of coffees consumed in Japan, was taken as the basis. A survey of technical manuals of roasting equipment for at least 2 standard $60 \mathrm{~kg}$ bags of green coffee per batch was undertaken to obtain the input energy figures for both gas and electricity at the longer end of the specified roasting duration. 
Pre-print version. Please refer to the published version:

Hassard H.A., Couch M.H., Techa-Erawan T., Mclellan B.C.. Product carbon footprint and energy analysis of alternative coffee products in Japan. Journal of Cleaner Production. 73( ), 310-321 (2014) http://dx.doi.org/10.1016/i.jclepro.2014.02.006.

Greenhouse gas emissions from the energy used in the roasting process were estimated using emissions factors for the specified electricity mix and gas combustion (6.02 $\mathrm{kg} \mathrm{CO}_{2}$-eq / MJ) (JEMAl, 2012). Emissions of $\mathrm{CO}_{2}$ from the roasting process itself were estimated the upper end of figures quoted in (Illy and Viani, 2005) as would be expected from a higher temperature or darker roast. The maximum value from the range of 6-10 $\mathrm{L} \mathrm{CO}_{2} / \mathrm{kg}$ green beans (equivalent to $11.8-19.6 \mathrm{~g} \mathrm{CO}_{2} / \mathrm{kg}$ green beans) was used (IIly and Viani, 2005), with the $\mathrm{CO}_{2}$ release from the beans in the postroasting phase prior to brewing assumed to be included in this figure.

\subsubsection{Grinding}

Grinding of beans was assumed to be mechanical grinding based on a standard popular-brand commercial-size electrical grinder used at the café assisting this study. The energy usage was estimated from technical data for the grinder. Although large scale grinding utilised in the production of instant and canned coffee may be slightly more efficient, this difference is considered to be marginal, and hence the same grinding figures are utilised for all coffee production routes. Moreover, grinding power is a small contribution to the overall energy and PCF. Grinder rated electric power draw is $550 \mathrm{~W}$ and the rate of grinding is $3.7-4.7 \mathrm{~g} / \mathrm{s}$ with the lower rate assumed only for espresso (requiring a finer grind).

\subsubsection{Brewing}

The brewing processes for coffee are one of the most varied and important stages in the production process. Table 3 lists the serving size and typical range of roast coffee, water and milk requirements per serving for the alternatives investigated in this study. The instant and canned coffee brewing is undertaken at a factory, whereas the remaining alternatives are brewed at the site of retail and / or consumption. The instant and canned coffee brewing impacts are separated from the usage phase, and have thus been included in the roasted coffee production for the purpose of presentation of results. Energy and emissions for the production of instant coffee were obtained from the environmental reports data of a major operation in Japan (Nestle, 2010).

An additional energy consuming step for the canned coffee is its storage in a hot cabinet or vending machine prior to retail, whereas the other options are not (although the drip coffee is kept heated until sold or disposed of, which is accounted for in the brewing energy). In this case, the energy for storage was estimated based on a vending machine, with allocation of total energy based on the volume of a can of coffee as a fraction of the total stored volume. The energy incurred by this storage was estimated on the basis of 1 day and 1 week of storage per serve prior to consumption, with the average presented based on 3 days. The energy usage of the vending machine was obtained from the manufacturer's power label which indicates the yearly average consumption. 
Pre-print version. Please refer to the published version:

Hassard H.A., Couch M.H., Techa-Erawan T., Mclellan B.C.. Product carbon footprint and energy analysis of alternative coffee products in Japan. Journal of Cleaner Production. 73( ), 310-321 (2014) http://dx.doi.org/10.1016/i.jclepro.2014.02.006.

Table 4: Basic serving sizes, water, milk and coffee requirement for each coffee product evaluated

\begin{tabular}{|c|c|c|c|c|c|}
\hline Product & $\begin{array}{l}\begin{array}{l}\text { Roast } \\
\text { coffee }\end{array} \\
\text { (g / serve) }\end{array}$ & $\begin{array}{l}\begin{array}{l}\text { Serving } \\
\text { size }\end{array} \\
(\mathrm{mL})\end{array}$ & $\begin{array}{l}\begin{array}{l}\text { Water } \\
\text { use }^{+}\end{array} \\
(\mathrm{mL})\end{array}$ & $\begin{array}{l}\text { Milk } \\
\text { (mL) }\end{array}$ & Brewing equipment \\
\hline Espresso & $7-8$ & 30 & 39 & & $\begin{array}{l}\text { Commercial espresso } \\
\text { machine ( } 2 \text { head) }\end{array}$ \\
\hline $\begin{array}{l}\text { Espresso -regular } \\
\text { Long black* }\end{array}$ & $7-8$ & 230 & 239 & & $\begin{array}{l}\text { Commercial espresso } \\
\text { machine ( } 2 \text { head) }\end{array}$ \\
\hline $\begin{array}{l}\text { Espresso -regular } \\
\text { Latte }^{\#}\end{array}$ & $7-8$ & 230 & 39 & 150 & $\begin{array}{l}\text { Commercial espresso } \\
\text { machine ( } 2 \text { head) }\end{array}$ \\
\hline Drip filter & $14-17$ & 230 & 255 & & Commercial coffee brewer \\
\hline Press & $5-10$ & 230 & 245 & & $1 \mathrm{~L}$ electric kettle $(1 \mathrm{~kW})$ \\
\hline One-cup filter & $7-15$ & 230 & 253 & & 1L electric kettle (1kW) \\
\hline Instant ${ }^{\wedge}$ & $5-9$ & 230 & 243 & & $\begin{array}{l}\text { Factory - industrial-scale } \\
\text { brewer; } \\
\text { User - 1L electric kettle } \\
(1 \mathrm{~kW})\end{array}$ \\
\hline $\operatorname{Can}^{\wedge}$ & $9-19$ & 190 & 198 & 27 & $\begin{array}{l}\text { Factory - industrial-scale } \\
\text { brewer; } \\
\text { Storage - hot cabinet; } \\
\text { or, vending machine; }\end{array}$ \\
\hline
\end{tabular}

Notes:

${ }^{+}$Water use includes the amount of water input - some of this is absorbed by the coffee grounds.

* Espresso made-up to volume with hot water;

Milk is expressed as volume of unfrothed milk. A Latte is $30 \mathrm{~mL}$ espresso made-up to volume with frothed milk; frothed milk density provides the difference between the serving size and the sum of added component volumes..

IInstant and can coffee water requirement includes water in waste coffee grounds at the factory.

\subsubsection{Distribution}


Pre-print version. Please refer to the published version:

Hassard H.A., Couch M.H., Techa-Erawan T., Mclellan B.C.. Product carbon footprint and energy analysis of alternative coffee products in Japan. Journal of Cleaner Production. 73( ), 310-321 (2014) http://dx.doi.org/10.1016/i.jclepro.2014.02.006.

Distribution of coffee beans and products was assumed to be undertaken by road transportation. The length of specific distribution routes were estimated using Google Maps ${ }^{\circledR}$ given the approximate locations of storage and processing facilities, and with the end use point of Kyoto University. The average road-based route distances are shown in Table 4, although a sensitivity analysis on the use of non-road transportation methods was also undertaken. All transport was assumed to be in $10 \mathrm{t}$ trucks at $100 \%$ load, with an emissions factor of $0.101 \mathrm{~kg} \mathrm{CO}_{2}$-eq / ntk (JEMAI, 2012).

Table 5: Domestic coffee and coffee product distribution routes and average route distances

\begin{tabular}{lllll}
\hline Product & Roasting facility Warehouse / Factory Retail Total distance
\end{tabular}

$(\mathbf{k m})$

\begin{tabular}{llllc}
\hline Espresso & Yokohama & Osaka & Kyoto University & 580 \\
Drip filter & Yokohama & Osaka & Kyoto University & 580 \\
Press & Yokohama & Osaka & Kyoto University & 580 \\
One-cup filter & Yokohama & Osaka & Kyoto University & 580 \\
Instant & Kobe & Kobe & Kyoto University & 185 \\
Can & Yokohama & Shizuoka & Kyoto University & 460 \\
\hline
\end{tabular}

\subsubsection{Milk}

The production of milk, from farming through processing and delivery is an important contributor to the overall carbon footprint in coffee products. In the current study, the farming and processing impacts were sourced from secondary studies relating specifically to milk production in Japan (Ogino et al., 2008) where possible, or from non-Japanese studies if not available but considered to be acceptable (e.g. processing technologies that are comparable internationally) (Meneses et al., 2012; Milani et al., 2011; Ramírez et al., 2006; Thomassen et al., 2008). The source of milk was indicated as Hokkaido in Japan, and the mode of transportation and estimates of the processing impacts of milk were obtained from the Morinaga milk company CSR report (Morinaga, 2011).

Transportation impacts were calculated for all except the canned product by two alternative bimodal transport routes: (1) shipped from Hokkaido to Kyoto prefecture then transported by truck; and, (2) by rail from Hokkaido to Kyoto prefecture then transported by truck. For the canned product, it is assumed that the canning occurs in Shizuoka, with the milk being transported there by ship or rail. The assumed transportation distances and emissions factors are given in Table 5. In all cases, an additional $50 \mathrm{~km}$ of truck transport is assumed for collection of the milk and transport to port in Hokkaido. In all cases, truck and ship transportation used emissions factors including refrigeration (JEMAI, 2012). 
Pre-print version. Please refer to the published version:

Hassard H.A., Couch M.H., Techa-Erawan T., Mclellan B.C.. Product carbon footprint and energy analysis of alternative coffee products in Japan. Journal of Cleaner Production. 73( ), 310-321 (2014) http://dx.doi.org/10.1016/i.jclepro.2014.02.006.

Table 6: Data on milk transportation from Hokkaido to the site of usage

\begin{tabular}{|c|c|c|c|c|c|}
\hline & $\begin{array}{l}\text { Major } \\
\text { mode }\end{array}$ & $\begin{array}{c}\text { Ship / rail } \\
\text { transport } \\
(\mathbf{k m})\end{array}$ & $\begin{array}{c}\text { Emissions } \\
\text { factor } \\
\text { (kg CO})_{2}^{-e q ~ / ~} \\
n t k)\end{array}$ & $\begin{array}{c}\text { Truck } \\
\text { Transport } \\
(\mathbf{k m})^{\#}\end{array}$ & $\begin{array}{l}\text { Emissions factor } \\
\text { (kg CO} \\
\text {-eq / ntk) }\end{array}$ \\
\hline \multirow[t]{3}{*}{$\begin{array}{l}\text { Hokkaido - } \\
\text { Kyoto }\end{array}$} & Ship & 1,050 & 0.026 & $\begin{array}{l}\text { a) } 104 \\
+\end{array}$ & 0.11 \\
\hline & & & & b) 7 & 1.16 \\
\hline & Rail & 1,530 & 0.011 & b) 7 & 1.16 \\
\hline \multirow[t]{2}{*}{$\begin{array}{l}\text { Hokkaido - } \\
\text { Shizuoka }\end{array}$} & Ship & 1,390 & 0.026 & & \\
\hline & Rail & 1,240 & 0.011 & & \\
\hline
\end{tabular}

Notes: ${ }^{\#}$ Truck transport from (a) port to Kyoto station by 10 refrigerated truck at $100 \%$ load; and (b) Kyoto station to Kyoto University by refrigerated light van at $50 \%$ load;

\subsubsection{Packaging}

The amount of packaging associated with each of the individual items was directly measured. Packaging associated with bulk-transportation was estimated where direct observation was not possible. Hot canned coffee almost always comes in steel cans of $190 \mathrm{~mL}$ volume (larger cold coffee and very rarely larger hot coffee cans are made of aluminium). Paper coffee cups with plastic lids are shown in this section but kept separate in the data so as to examine the impact of reusable cups at the café (described in the discussion). Roasted beans (where grinding occurs at the home or retail outlet) are packaged in a laminate plastic pack containing $200 \mathrm{~g}$ coffee. The details of applicable packaging are given in Table 6. 
Pre-print version. Please refer to the published version:

Hassard H.A., Couch M.H., Techa-Erawan T., Mclellan B.C.. Product carbon footprint and energy analysis of alternative coffee products in Japan. Journal of Cleaner Production. 73( ), 310-321 (2014) http://dx.doi.org/10.1016/i.jclepro.2014.02.006.

Table 7: Packaging inventory items assessed in the current study

\begin{tabular}{|c|c|c|}
\hline Product & $\begin{array}{l}\text { Mass of } \\
\text { packaging }\end{array}$ & Description \\
\hline Paper cup & $12 \mathrm{~g}$ & $281 \mathrm{~mL}$ cardboard cup \\
\hline Plastic lid for cup & $2 \mathrm{~g}$ & Polyethylene \\
\hline Steel can & $33 g$ & $190 \mathrm{~mL}$ coffee can \\
\hline Milk carton & $31 \mathrm{~g}$ & $1 \mathrm{~L}$ milk carton \\
\hline Roasted bean pack & $10 \mathrm{~g}$ & $\begin{array}{l}\text { Plastic pack for roasted coffee beans } \\
-200 \mathrm{~g} \text { (Polypropylene and PET) }\end{array}$ \\
\hline One-cup filter bag & $1.5 \mathrm{~g}$ & Filter bag and cardboard support \\
\hline One-cup filter pack & $1.5 \mathrm{~g}$ & Plastic single-serve wrap for filter \\
\hline Glass bottle - small (1) & $111 \mathrm{~g}$ & Instant coffee $-30 \mathrm{~g}$ bottle \\
\hline Plastic lid for (1) & $10 \mathrm{~g}$ & Polypropylene \\
\hline $\begin{array}{l}\text { Paper labels and seals for } \\
\text { (1) }\end{array}$ & $1 \mathrm{~g}$ & \\
\hline Glass bottle - large (2) & $322 \mathrm{~g}$ & Instant coffee $-150 \mathrm{~g}$ bottle \\
\hline Plastic lid for (2) & $18 \mathrm{~g}$ & Polypropylene \\
\hline $\begin{array}{l}\text { Paper labels and seals for } \\
\text { (2) }\end{array}$ & $2 g$ & \\
\hline
\end{tabular}

Energy and emissions data for packaging was obtained from previous life cycle assessments on packaging items undertaken in Japan, which were specific to the packaging products or materials used in this study (bottles, cans, milk carton (Ministry of the Environment (Government of Japan), 2004); cup and lid (Tokan Kogyo, 2010); plastic and paper (JEMAI, 2012)).

\subsubsection{Waste disposal}

Waste disposal for both spent coffee grounds and packaging materials were examined. The current disposal of these materials is very similar within the context of Kyoto - the cans, milk cartons, cups and coffee grounds are all sent to one of the local "clean centers" using $100 \%$ waste oil-derived biodiesel-fuelled garbage trucks (Environmental Policy Bureau, 2012). Cans are recycled, while the 
Pre-print version. Please refer to the published version:

Hassard H.A., Couch M.H., Techa-Erawan T., Mclellan B.C.. Product carbon footprint and energy analysis of alternative coffee products in Japan. Journal of Cleaner Production. 73( ), 310-321 (2014) http://dx.doi.org/10.1016/i.jclepro.2014.02.006.

other materials are combusted to produce electricity that runs the clean center and some energy is exported to the grid. In the case of instant and canned coffee, coffee grounds are considered to be combusted for energy recovery, as has been undertaken by a number of global instant coffee producers. Plastic is transported in regular diesel garbage trucks for recycling elsewhere. Due to the Kyoto University's position as a large producer of waste, it was assumed that the transport of waste was direct from the university to the clean center (rather than via any other customers). Distance to waste disposal facilities are $9-11 \mathrm{~km}$. Under PAS 2050, the use of biodiesel from waste oil incurs the carbon footprint from the point of waste conversion to fuel through combustion.

A number of alternative waste disposal routes can be considered as a potential option for reducing emissions or valorising this waste stream, which has been estimated to total 9168 tonnes / year (wet coffee grinds and tea leaves) in Kyoto $\mathrm{City}^{2}$ (Matsuda et al., 2012). As an energy source, straight combustion would yield approximately $2.4 \mathrm{kWh} / \mathrm{kg}$ of thermal energy (based on calorific value from (Silva et al., 1998)), which (at 30\% efficiency) might generate $22 \mathrm{GWh}$ of electricity (or close to $3 \%$ of the city's electricity usage). Other uses, such as anaerobic digestion to produce methane (approximately $0.3 \mathrm{~m}^{3} \mathrm{CH}_{4} / \mathrm{kg}$ )(Lane, 1983), production of activated carbon (Takahata et al., 2009), co-firing with coal and waste plastic (Furuyama et al., 2009) or extraction of useful oil and gas components via pyrolysis (Bok et al., 2012; Romeiro et al., 2012), the use of supercritical fluids (Couto et al., 2009) or solvent extraction (Al-Hamamre et al., 2012) have also been examined as potentially beneficial alternatives. The total utilisation of spent coffee grounds to produce oil, biodiesel and biochar has also been examined in combination as a comprehensive coffee waste utilisation strategy (Vardon et al., 2013).

For the sake of this assessment, the use of spent coffee grounds to produce electricity is the only route considered. According to PAS:2050, the emissions generated by this combustion are an emission associated with the electricity and the avoidance of grid electricity is a removal allocated to the energy system - both of these we have included within the PCF.

\section{Results}

The overall results of energy analysis and the PCF for the alternative coffee products are shown in Figure 4. Figure 5 then breaks down the total embodied energy (EE) or PCF into the major component stages. Negative values indicate carbon absorption and energy credits applied for the energy recovery from waste.

\footnotetext{
${ }^{2}$ This referenced figure includes tea leaves and coffee grounds.
} 
Pre-print version. Please refer to the published version:

Hassard H.A., Couch M.H., Techa-Erawan T., Mclellan B.C.. Product carbon footprint and energy analysis of alternative coffee products in Japan. Journal of Cleaner Production. 73( ), 310-321 (2014) http://dx.doi.org/10.1016/i.jclepro.2014.02.006.

Figure 4 indicates that the range of energy consumption between an Espresso $(0.126 \mathrm{kWh} /$ serve) and canned coffee ( $0.762 \mathrm{kWh} /$ serve) is particularly significant, while a Latte $(0.542 \mathrm{kWh} /$ serve) also has the second highest EE. Figure 5 indicates that the inclusion of milk as well as the embodied energy of the steel can are the highest contributions in this case. The processing of coffee cherries to green coffee is also a significant contributor to embodied energy.

With regards to the PCF, Figure 4 indicates that on a per serve basis, the lowest PCF is again for Espresso ( $48.6 \mathrm{~g} \mathrm{CO}_{2}$-eq / serve), and is approximately 4 times lower than the highest PCF (for a Latte, $233.7 \mathrm{~g} \mathrm{CO}_{2}$-eq / serve). In this case again, the milk is the largest contributor - in the latte product particularly.

Comparison on the basis of alternative functional units gives a greater understanding of the potential for varying results. The data on the basis of the impact: (a) per serve, (b) per millilitre of coffee product, and (c) per gram of roasted coffee utilized, are also shown in Figure 4. On the basis of the carbon footprint, the Latte is the highest impact per gram of coffee $\left(33.4 \mathrm{~g} \mathrm{CO}_{2}\right.$-eq / g roasted coffee), followed by canned coffee ( $11.8 \mathrm{~g} \mathrm{CO}_{2}$-eq / g roasted coffee) and then instant (6.9 $\mathrm{g} \mathrm{CO}_{2}$-eq / $\mathrm{g}$ roasted coffee), with the one-cup filter as the lowest impact (5.4 $\mathrm{g} \mathrm{CO}_{2}$-eq / g roasted coffee). In the case of energy consumption, the highest impact products are likewise the Latte, can and instant - however the proportional difference between the Latte and can is lower than for the PCF.

Per milliliter of product, a significant difference in the order of results is apparent. The espresso (1.62 $\mathrm{g} \mathrm{CO}_{2}$-eq $\left./ \mathrm{mL}\right)$, canned coffee $\left(1.17 \mathrm{~g} \mathrm{CO}_{2}\right.$-eq $\left./ \mathrm{mL}\right)$ and then the Latte $\left(1.02 \mathrm{~g} \mathrm{CO}_{2}\right.$-eq / $\left.\mathrm{mL}\right)$ are the highest impact products (in order). This has a significant implication for the comparison of alternative coffee products, as the energy and emissions of equal-volume serves will also carry over this ranking.

Alternative product packaging for canned coffee is one potential focus for reduction of both energy ( $0.46 \mathrm{kWh} /$ serve or $60 \%$ of the EE) and carbon footprint (103 g CO2-eq / serve or $46 \%$ of the PCF). All canned coffee products surveyed in local convenience stores and vending machines are contained in the same type of steel can - in contrast to other beverages, which are often contained in Aluminium cans. Aluminium cans weigh approximately half the equivalent steel can $112 \mathrm{~g}$ for Aluminium, 32g for steel), which could lower transportation impacts. However, the higher embodied energy and carbon of Aluminium make switching to Aluminium ineffective in reducing the PCF rather, it is likely to increase the PCF.

The latte product (as one of the highest impact products) is taken as an example for further analysis. The breakdown of the stages in the previous figures is show in Figure 6 and Figure 7 to indicate the major contributing operations to the EE and PCF respectively. The processing of coffee through to green beans is the key area of impact, due to highly inefficient operations and the production of large amounts of waste water which is often not well utilized (Adams and Ghaly, 2007). The particularly high level of energy usage indicates low efficiency in the provision of heat, which could benefit significantly from the intervention and assistance of coffee purchasing companies. 
Pre-print version. Please refer to the published version:

Hassard H.A., Couch M.H., Techa-Erawan T., Mclellan B.C.. Product carbon footprint and energy analysis of alternative coffee products in Japan. Journal of Cleaner Production. 73( ), 310-321 (2014) http://dx.doi.org/10.1016/i.jclepro.2014.02.006.

The inclusion of carbon absorption by the coffee plants (not including coffee itself) is significant in regards to its potential reduction of the emissions of the lifecycle. Figure 8 shows that the overall PCF can be reduced by including the net carbon absorption by the coffee plantation (approximately $2.98 \mathrm{~g} \mathrm{CO}_{2}$-eq / g green coffee beans - estimated from average coffee yield (Coltro et al., 2006) and sequestration rate for one year (Hergoualc'h et al., 2012)). If included as a removal, this subsequent reduction in the total PCF would be $11 \%$ in the case of the Latte, or up to $66 \%$ reduction for a onecup filter.

\subsection{Sensitivity to electricity mix}

While the largest contribution to the PCF has been indicated to be the production of green coffee beans, the electricity mix can also affect the PCF, and is one of the factors that is able to be changed through investment or retail selection in the country of coffee consumption (Japan). The electricity situation in Japan in the post-Fukushima era is yet to reach a final conclusion with regards to the ongoing acceptance or rejection of nuclear power, and a variety of potential futures have been examined and found technically feasible (McLellan et al., 2013). The base case scenario here was therefore tested to determine the impact of current (restricted nuclear) and alternative energy mixes. The alternative mixes reflect the potential emissions factors of the real electricity generation mix over the period 2011-2013, which has had periods of time without any nuclear power active. The alternatives indicate a no-nuclear scenario with the nuclear portion being replaced by the indicated mix of coal, gas or the existing non-nuclear mix (Table 7).

Table 8: Potential alternative energy mixes considered in the study

\begin{tabular}{ll}
\hline Energy mix & Emissions Factor \\
& ( g CO2 / kWh) \\
\hline Current (2010) & 311 \\
\hline No nuclear - 50\% gas/50\% coal & 415.6 \\
\hline No nuclear - 100\% coal & 509.2 \\
\hline No nuclear - current non-nuclear mix & 558.8 \\
\hline No nuclear - 100\% gas & 322.1 \\
\hline
\end{tabular}

Figure 9 (a) indicates the results of this analysis, showing that overall the electricity mix only produces a small effect on the PCF. 
Pre-print version. Please refer to the published version:

Hassard H.A., Couch M.H., Techa-Erawan T., Mclellan B.C.. Product carbon footprint and energy analysis of alternative coffee products in Japan. Journal of Cleaner Production. 73( ), 310-321 (2014) http://dx.doi.org/10.1016/i.jclepro.2014.02.006.

\subsection{Sensitivity to amount of roasted, ground coffee}

The sensitivity of the PCF to the amount of roasted coffee used in the production of the beverage was analysed in order to examine the impact of error in sample size and the selection of alternative products. The range of mixes was examined as shown in Table 3. This range reflects that in the case of espresso there is a small variation in the amount of roasted coffee utilised, while alternative one-cup drip filter products and canned coffee products have a wide range of roasted coffee pre-cursor, depending on the manufacturer. For drip, press and instant coffee, the range represented the amount of variability of samples from five alternative preparers of coffee, and is more representative of personal taste rather than error in standard serving size.

The results (Figure 9 (b)) show much larger variation than the electricity mix. In the case of canned coffee and one-cup filter, high coffee content alternative products have up to approximately $100 \%$ extra roasted coffee per serve than low coffee content products, which exacerbates the impact of the emissions associated with the cultivation and processing of the beans.

\subsection{Comparison with organic farming}

The carbon footprint associated with conventional farming was compared with organic farming, both emissions factors being taken from the same previous study (Noponen et al., 2012). The results in Figure 9 (c) indicate that there is a significant potential variation in coffee PCF associated with a lower utilisation of inorganic fertilisers and agricultural treatments.

\section{Discussion}

The results that are discussed above indicate that there is a significant range of EE and PCF, however, it is important to note that the figures calculated in this study also present a different picture of the PCF for coffee products compared with previous studies. The comparable products are shown in Table 8. These figures indicate that the energy consumption is in a similar range, while the greenhouse gas emissions are generally on the lower end of the spectrum. The difference may be attributed to the energy mix applied and the scope of the study. 
Pre-print version. Please refer to the published version:

Hassard H.A., Couch M.H., Techa-Erawan T., Mclellan B.C.. Product carbon footprint and energy analysis of alternative coffee products in Japan. Journal of Cleaner Production. 73( ), 310-321 (2014) http://dx.doi.org/10.1016/i.jclepro.2014.02.006.

Table 9: Comparison of the results of the current study with previous work

\begin{tabular}{|c|c|c|c|c|c|c|}
\hline \multirow[t]{2}{*}{ Product } & \multirow{2}{*}{$\begin{array}{l}\text { Impact } \\
\text { category }\end{array}$} & \multicolumn{5}{|c|}{ Study } \\
\hline & & $\begin{array}{l}\text { This } \\
\text { study }\end{array}$ & $\begin{array}{l}\text { Büsser (Büsser } \\
\text { and Jungbluth, } \\
\text { 2009) }\end{array}$ & $\begin{array}{l}\text { Humbert } \\
\text { (Humbert et al., } \\
\text { 2009) }\end{array}$ & $\begin{array}{l}\text { Tchibo } \\
\text { (Tchibo, } \\
\text { 2009) }\end{array}$ & $\begin{array}{l}\text { JEMAI } \\
\text { (JEMAI, } \\
2010 \text { ) }\end{array}$ \\
\hline \multirow[t]{2}{*}{ Espresso } & $\begin{array}{l}\text { Energy (kWh } \\
\text { / serve) }\end{array}$ & 0.13 & 0.19 & & & \\
\hline & $\begin{array}{l}\mathrm{GHG}\left(\mathrm{g} \mathrm{CO}_{2^{-}}\right. \\
\text {eq / serve) }\end{array}$ & 49 & 90 & & & \\
\hline \multirow[t]{2}{*}{ Instant } & $\begin{array}{l}\text { Energy (kWh } \\
\text { / serve) }\end{array}$ & 0.24 & 0.25 & $0.35^{\mathrm{a}}$ & & \\
\hline & $\begin{array}{l}\text { GHG ( } \mathrm{g} \mathrm{CO}_{2^{-}} \\
\text {eq / serve) }\end{array}$ & 50 & 80 & 74 & & 101 \\
\hline \multirow[t]{2}{*}{$\begin{array}{l}\text { Drip } \\
\text { filter }\end{array}$} & $\begin{array}{l}\text { Energy (kWh } \\
\text { / serve) }\end{array}$ & 0.23 & & $0.60-0.74^{a}$ & & \\
\hline & $\begin{array}{l}\text { GHG ( } \mathrm{g} \mathrm{CO}_{2^{-}} \\
\text {eq / serve) }\end{array}$ & 88 & & $120-150$ & 60 & \\
\hline
\end{tabular}

${ }^{a}$ Humbert energy figures are given as primary energy - whereas energy in this study is final energy consumption.

\subsection{Carbon and cost savings under a retail bonus scheme}

As a corporate social responsibility activity one of the retailers examined has implemented a scheme whereby the customer receives approximately $10 \%$ discount on a cup of coffee (average price is $¥ 300$ - 350) if they supply their own reusable cup. Furthermore, Kyoto City offers (for part of the year) the opportunity for the consumer to receive the equivalent of $¥ 50$ per cup of coffee if the customer brings a reusable cup or tumbler. This prompted an examination of the equivalent carbon abatement cost that is being offered in this case. In order to calculate this, the value to the parties involved is calculated, and divided by the net emissions from the production of the disposable cup and lid and additional the emissions from washing the reusable cup. This net emission is approximately $15.1 \mathrm{~g} \mathrm{CO}_{2}$-eq / serve.

Given that the disposable cup and lid cost the company at most $¥ 10.5$ per set, and that the water, labour and energy cost of washing a reusable cup (if undertaken by the coffee retailer) would 
Pre-print version. Please refer to the published version:

Hassard H.A., Couch M.H., Techa-Erawan T., Mclellan B.C.. Product carbon footprint and energy analysis of alternative coffee products in Japan. Journal of Cleaner Production. 73( ), 310-321 (2014) http://dx.doi.org/10.1016/i.jclepro.2014.02.006.

be minimal, then the savings to the company are around $¥ 10.5$. (It should be noted that the carbon emissions from washing may be significantly different - and can even outweigh the benefit of a reusable cup, depending on the customer behaviour (Humbert et al., 2009)). The customer receives a $¥ 30$ discount on their coffee and $¥ 50$ worth of public transport or goods from Kyoto City. This gives the equivalent cost of abatement from the perspective of the various parties involved as shown in Figure 10. By way of comparison, the Australian carbon tax (as of 2012) was approximately $¥ 2000$ per tonne (\$23 AUD (Commonwealth of Australia, 2011)) (3 orders of magnitude lower).

\subsection{Total Japanese coffee carbon footprint}

Given the results of this study and the breakdown of coffee consumption in Japan (AJCA, 2012) shown in Figure 11 (neglecting liquid coffee other than canned coffee), the overall carbon footprint of coffee consumption in Japan can be estimated. Table 10 shows that the overall carbon footprint of coffee consumed in Japan is approximately $2,881 \mathrm{kt} \mathrm{CO}_{2}$-eq, largely dominated by canned coffee (more than half of the footprint). This is despite the market share of canned coffee being only $17 \%$ of consumption.

Table 10: Coffee product consumption and total carbon footprint for coffee in Japan

Coffee product $\quad$ Units Carbon footprint

(kt $\mathrm{CO}_{2}$-eq)

\begin{tabular}{lrll}
\hline Roasted & 262,561 & $\mathrm{t}$ & 897 \\
Instant & 43,143 & $\mathrm{t}$ & 321 \\
& & & \\
Canned & $2,025,000$ & $\mathrm{~kL}$ & 1,663 \\
Other RTD & 852,000 & $\mathrm{~kL}$ & - \\
& & Total & $\mathbf{2 , 8 8 1}$ \\
& & & \\
\hline
\end{tabular}

Notes: Roasted coffee assumed to be consumed as drip filter coffee

\section{Conclusions}

This study provides a comprehensive carbon footprint analysis for the six popular forms of coffee consumed today in Japan. This paper uses coffee choices available on and around the Kyoto University campus as case studies, which are taken to be representative of coffee products available around Japan (the saturated and highly competitive state of the Japanese coffee market has allowed this assumption, with a high level of homogeneity among the products available). This study was 
Pre-print version. Please refer to the published version:

Hassard H.A., Couch M.H., Techa-Erawan T., Mclellan B.C.. Product carbon footprint and energy analysis of alternative coffee products in Japan. Journal of Cleaner Production. 73( ), 310-321 (2014) http://dx.doi.org/10.1016/i.jclepro.2014.02.006.

designed to be easily comparable with previous literature, also filling gaps with regard to the multiple options available to coffee drinkers.

The results demonstrated wide variations in environmental impacts across the respective coffee products, and compelling reasons for these differences. A particularly stark contrast was between two forms of coffee often grouped together (on the luxury end of the product scale), namely the espresso and the latte. The latter had a significantly higher PCF, or environmental impact, due primarily to the high carbon emissions required for milk production. This data may be valuable to coffee firms or citizens keen to reduce their environmental impact.

The other significant result, particularly in a Japanese context, was the effect of packaging on the overall energy embedded in the canned coffee product. The phenomenon of canned coffee arguably typifies Japanese coffee drinking culture, a style of beverage rarely seen elsewhere; the can itself provides easy transportation, instant availability, and coffee vending machines are ubiquitous across the country. Despite only holding around $17 \%$ of the market share of consumed coffee, the canned coffee product contributes around half of the national carbon footprint from coffee consumption.

As the 3rd largest importers of coffee globally, the drinking of coffee is spread far and wide across the Japanese population, and hence offers a societally relevant product for analysis. The social impact of coffee in commodity-exporting countries has been well documented (Raynolds et al., 2007; Valkila, 2009; Wilson, 2010), whereas the other end of the spectrum has not been elucidated to the same extent. Further studies could therefore include an investigation of consumer behaviour, with and without the knowledge of the relative impacts of each coffee form.

This study introduced three alternative functional units - the "serve" of coffee, a millilitre of product and the gram of roasted coffee utilised. Significantly, the serve and the volumetric functional unit express very different results, indicating that there is a potential for misleading or confusing the footprint.

\section{References}

Adams, M., Ghaly, A.E., 2007. Maximizing sustainability of the Costa Rican coffee industry. Journal of Cleaner Production 15, 1716-1729.

AJCA, 2012. Coffee Market in Japan. All Japan Coffee Association, Tokyo.

Al-Hamamre, Z., Foerster, S., Hartmann, F., Kröger, M., Kaltschmitt, M., 2012. Oil extracted from spent coffee grounds as a renewable source for fatty acid methyl ester manufacturing. Fuel 96 , 70-76.

Bacon, C., 2005. Confronting the Coffee Crisis: Can Fair Trade, Organic, and Specialty Coffees Reduce Small-Scale Farmer Vulnerability in Northern Nicaragua? World Development 33, 497511.

Bok, J.P., Choi, H.S., Choi, Y.S., Park, H.C., Kim, S.J., 2012. Fast pyrolysis of coffee grounds: Characteristics of product yields and biocrude oil quality. Energy 47, 17-24.

BSI, 2011. Publicly available specification: PAS 2050: Specification for the assessment of the life cycle greenhouse gas emissions of goods and services. British Standards Institute, London, p. 38. 
Pre-print version. Please refer to the published version:

Hassard H.A., Couch M.H., Techa-Erawan T., Mclellan B.C.. Product carbon footprint and energy analysis of alternative coffee products in Japan. Journal of Cleaner Production. 73( ), 310-321 (2014) http://dx.doi.org/10.1016/i.jclepro.2014.02.006.

Büsser, S., Jungbluth, N., 2009. The role of flexible packaging in the life cycle of coffee and butter. The International Journal of Life Cycle Assessment 14, 80-91.

Castro-Tanzi, S., Dietsch, T., Urena, N., Vindas, L., Chandler, M., 2012. Analysis of management and site factors to improve the sustainability of smallholder coffee production in Tarrazú, Costa Rica. Agriculture, Ecosystems \&amp; Environment 155, 172-181.

Chanakya, H.N., De Alwis, A.A.P., 2004. Environmental Issues and Management in Primary Coffee Processing. Process Safety and Environmental Protection 82, 291-300.

Coltro, L., Mourad, A.L., Oliveira, P.A.P.L.V., Baddini, J.P.O.A., Kletecke, R.M., 2006. Environmental profile of Brazilian green coffee. International Journal of Life Cycle Assessment 11, 16-21.

Commonwealth of Australia, 2011. Clean Energy Act 2011, in: Australia, C.o. (Ed.), C2011A00131. Commonwealth of Australia, Australia.

Couto, R.M., Fernandes, J., da Silva, M.D.R.G., Simões, P.C., 2009. Supercritical fluid extraction of lipids from spent coffee grounds. The Journal of Supercritical Fluids 51, 159-166.

Danse, M., Wolters, T., 2003. Sustainable coffee in the mainstream: The case of the SUSCOF Consortium in Costa Rica. Greener management international, 37-51.

De Monte, M., Padoano, E., Pozzetto, D., 2003. Waste heat recovery in a coffee roasting plant. Applied Thermal Engineering 23, 1033-1044.

De Monte, M., Padoano, E., Pozzetto, D., 2005. Alternative coffee packaging: an analysis from a life cycle point of view. Journal of Food Engineering 66, 405-411.

Doorn, M.R.J., Towprayoon, S., Vieira, S.M.M., Irving, W., Palmer, C., Pipatti, R., Wang, C., 2006. Wastewater Treatment and Discharge, 2006 IPCC Guidelines for National Greenhouse Gas Inventories. Intergovernmental Panel on Climate Change.

Environmental Policy Bureau, 2012. Environmental Policy Bureau of Kyoto City. Kyoto City Council, Kyoto.

FAO, 2012. Food and Agriculture Organization of the United Nations - Statistics. FAO, Rome.

Furuyama, T., Ohya, H., Dodbiba, G., 2009. Development of a Manufacturing Process of Biomass Solid Fuel with Wasted Coffee Beans and its $\mathrm{CO}<\mathrm{sub}>2</$ sub $>$ Assessment. Resources Processing 56, 21-25.

Hergoualc'h, K., Blanchart, E., Skiba, U., Hénault, C., Harmand, J.-M., 2012. Changes in carbon stock and greenhouse gas balance in a coffee (Coffea arabica) monoculture versus an agroforestry system with Inga densiflora, in Costa Rica. Agriculture, Ecosystems \&amp; Environment 148, 102-110.

Humbert, S., Loerincik, Y., Rossi, V., Margni, M., Jolliet, O., 2009. Life cycle assessment of spray dried soluble coffee and comparison with alternatives (drip filter and capsule espresso). Journal of Cleaner Production 17, 1351-1358.

ICO, 2012. International Coffee Organisation, London.

Illy, A., Viani, R., 2005. Espresso Coffee: The science of quality, 2nd ed. Elsevier Academic Press, London, p. 398.

JEMAI, 2010. Product Category Rule - Instant Coffee. Japan Environmental Management Association for Industry, Tokyo.

JEMAI, 2012. Carbon Footprint of Products. Japan Environmental Management Association for Industry, Tokyo.

KEPCO, 2011. Kansai Electric Power Company CSR Report 2011. Kansai Electric Power Company Osaka, p. 42.

Lane, A.G., 1983. Anaerobic digestion of spent coffee grounds. Biomass 3, 247-268. 
Pre-print version. Please refer to the published version:

Hassard H.A., Couch M.H., Techa-Erawan T., Mclellan B.C.. Product carbon footprint and energy analysis of alternative coffee products in Japan. Journal of Cleaner Production. 73( ), 310-321 (2014) http://dx.doi.org/10.1016/i.jclepro.2014.02.006.

Matsuda, T., Yano, J., Hirai, Y., Sakai, S.-i., 2012. Life-cycle greenhouse gas inventory analysis of household waste management and food waste reduction activities in Kyoto, Japan. The International Journal of Life Cycle Assessment, 1-10.

McLellan, B.C., Zhang, Q., Utama, N.A., Farzaneh, H., Ishihara, K.N., 2013. Analysis of Japan's postFukushima energy strategy. Energy Strategy Reviews.

Meneses, M., Pasqualino, J., Castells, F., 2012. Environmental assessment of the milk life cycle: The effect of packaging selection and the variability of milk production data. Journal of Environmental Management 107, 76-83.

Milani, F.X., Nutter, D., Thoma, G., 2011. Invited review: Environmental impacts of dairy processing and products: A review. Journal of Dairy Science 94, 4243-4254.

Ministry of the Environment (Government of Japan), 2004. Packaging lifecycle assessment research report (Japanese). Ministry of the Environment, Government of Japan, Tokyo. Morinaga, 2011. CSR Report (in Japanese). Morinaga Milk Industry Co. Ltd, Tokyo, p. 46. Nestle, 2010. Site Report - Himeji Factory. Nestle Group, Himeji, Japan.

Noponen, M.R.A., Edwards-Jones, G., Haggar, J.P., Soto, G., Attarzadeh, N., Healey, J.R., 2012. Greenhouse gas emissions in coffee grown with differing input levels under conventional and organic management. Agriculture, Ecosystems \&amp; Environment 151, 6-15.

Ogino, A., Ishida, M., Ishikawa, T., Ikeguchi, A., Waki, M., Yokoyama, H., Tanaka, Y., Hirooka, H., 2008. Environmental impacts of a Japanese dairy farming system using whole-crop rice silage as evaluated by life cycle assessment. Animal Science Journal 79, 727-736.

Ponte, S., 2002. The 'Latte Revolution'? Regulation, Markets and Consumption in the Global Coffee Chain. World Development 30, 1099-1122.

Ramírez, C.A., Patel, M., Blok, K., 2006. From fluid milk to milk powder: Energy use and energy efficiency in the European dairy industry. Energy 31, 1984-2004.

Raynolds, L., Murray, D., Heller, A., 2007. Regulating sustainability in the coffee sector: A comparative analysis of third-party environmental and social certification initiatives.

Agriculture and Human Values 24, 147-163.

Romeiro, G.A., Salgado, E.C., Silva, R.V.S., Figueiredo, M.K.K., Pinto, P.A., Damasceno, R.N., 2012. A study of pyrolysis oil from soluble coffee ground using low temperature conversion (LTC) process. Journal of Analytical and Applied Pyrolysis 93, 47-51.

SeaRates.Com, 2011. Port-to-Port distance calculator.

Silva, M.A., Nebra, S.A., Machado Silva, M.J., Sanchez, C.G., 1998. THE USE OF BIOMASS RESIDUES IN THE BRAZILIAN SOLUBLE COFFEE INDUSTRY. Biomass and Bioenergy 14, 457-467.

Takahata, T., Toda, I., Ono, H., Ohshio, S., Akasaka, H., Himeno, S., Kokubu, T., Saitoh, H., 2009. Detailed Structural Analyses of KOH Activated Carbon from Waste Coffee Beans. Japanese Journal of Applied Physics 48, 4.

Tchibo, 2009. Case study Tchibo Privat Kaffee Rarity Machare, PCF Pilot Project Germany. Tchibo GmbH, Berlin, p. 55.

Thomassen, M.A., van Calker, K.J., Smits, M.C.J., Iepema, G.L., de Boer, I.J.M., 2008. Life cycle assessment of conventional and organic milk production in the Netherlands. Agricultural Systems 96, 95-107.

Tokan Kogyo, 2010. Environmental Report 2010. Tokan Kogyo Group, Tokyo, p. 19. Valkila, J., 2009. Fair Trade organic coffee production in Nicaragua - Sustainable development or a poverty trap? Ecological Economics 68, 3018-3025. 
Pre-print version. Please refer to the published version:

Hassard H.A., Couch M.H., Techa-Erawan T., Mclellan B.C.. Product carbon footprint and energy analysis of alternative coffee products in Japan. Journal of Cleaner Production. 73( ), 310-321 (2014) http://dx.doi.org/10.1016/i.jclepro.2014.02.006.

Vardon, D.R., Moser, B.R., Zheng, W., Witkin, K., Evangelista, R.L., Strathmann, T.J., Rajagopalan, K., Sharma, B.K., 2013. Complete Utilization of Spent Coffee Grounds To Produce Biodiesel, BioOil, and Biochar. ACS Sustainable Chemistry \& Engineering 1, 1286-1294.

Wilson, B.R., 2010. Indebted to Fair Trade? Coffee and crisis in Nicaragua. Geoforum 41, 84-92. 
Pre-print version. Please refer to the published version:

Hassard H.A., Couch M.H., Techa-Erawan T., Mclellan B.C.. Product carbon footprint and energy analysis of alternative coffee products in Japan. Journal of Cleaner Production. 73( ), 310-321 (2014) http://dx.doi.org/10.1016/i.jclepro.2014.02.006.

\section{Figures}

Figure 1: General life cycle stages of the production of a serve of coffee (cradle to grave)

\section{Export-ready green bean production}

Coffee cultivation, harvesting, cherry processing, green bean storage

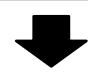

\section{Green bean transportation}

Domestic and international transportation to roasting plant

3. Roasting
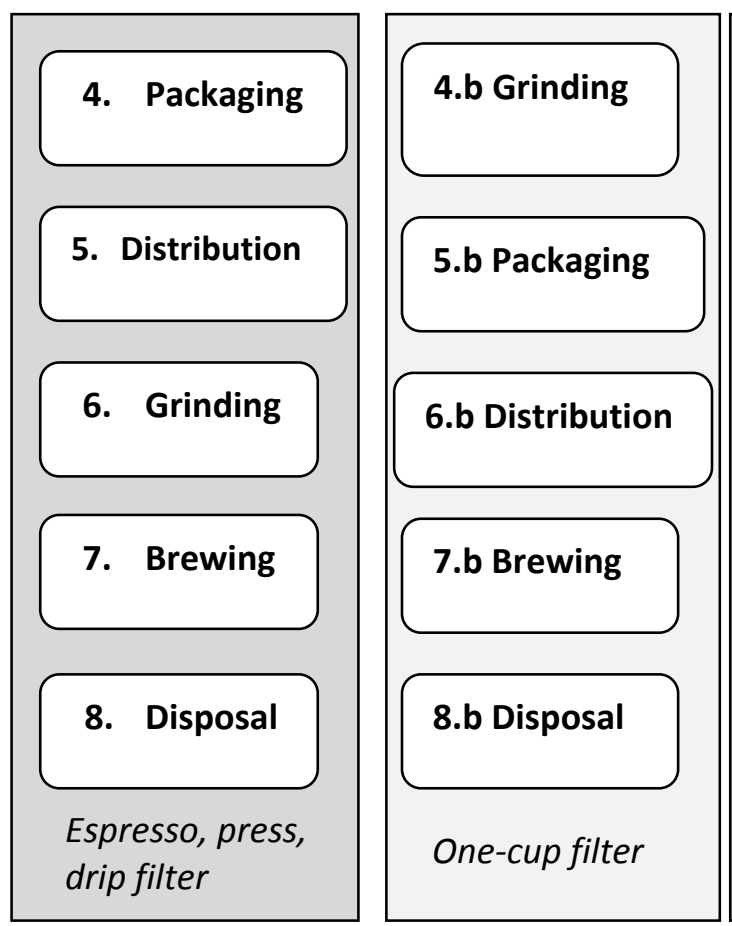

4.c Mass liquor brewing

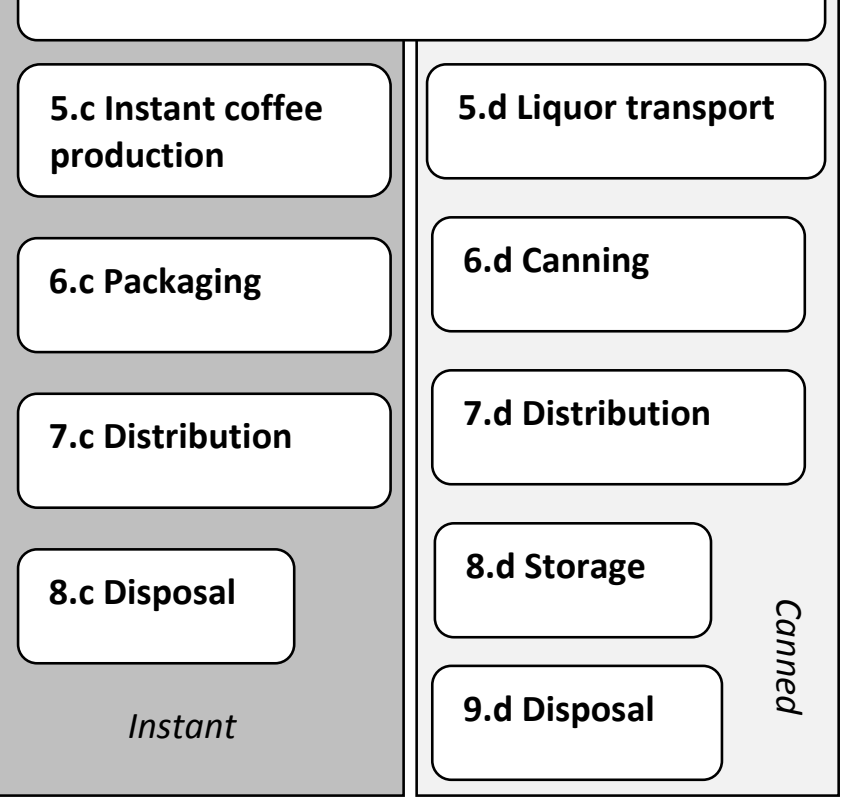


Pre-print version. Please refer to the published version:

Hassard H.A., Couch M.H., Techa-Erawan T., Mclellan B.C.. Product carbon footprint and energy analysis of alternative coffee products in Japan. Journal of Cleaner Production. 73( ), 310-321 (2014) http://dx.doi.org/10.1016/i.jclepro.2014.02.006.

Figure 2: Generalised flowsheet for export-ready green coffee bean production (adapted from Illy and Viani (2005))

\section{Process stage}

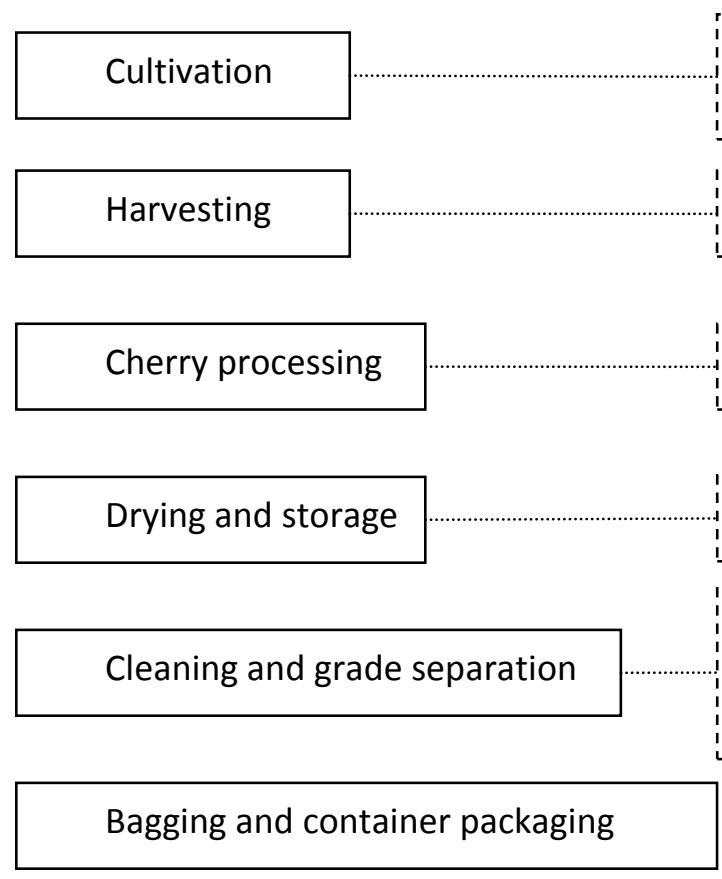

Alternatives / sub-processes

Conventional or organic;

Shaded or unshaded;

Mechanical or manual

Dry / Wet / Pulped Natural

Mechanical or natural

Pre-cleaning; destoning; hulling; polishing; size-grading; gravity separation; colour sorting;

Figure 3: Overall greenhouse gas emissions from green coffee bean transportation from alternative source countries (Note: domestic emissions are within the source country only)

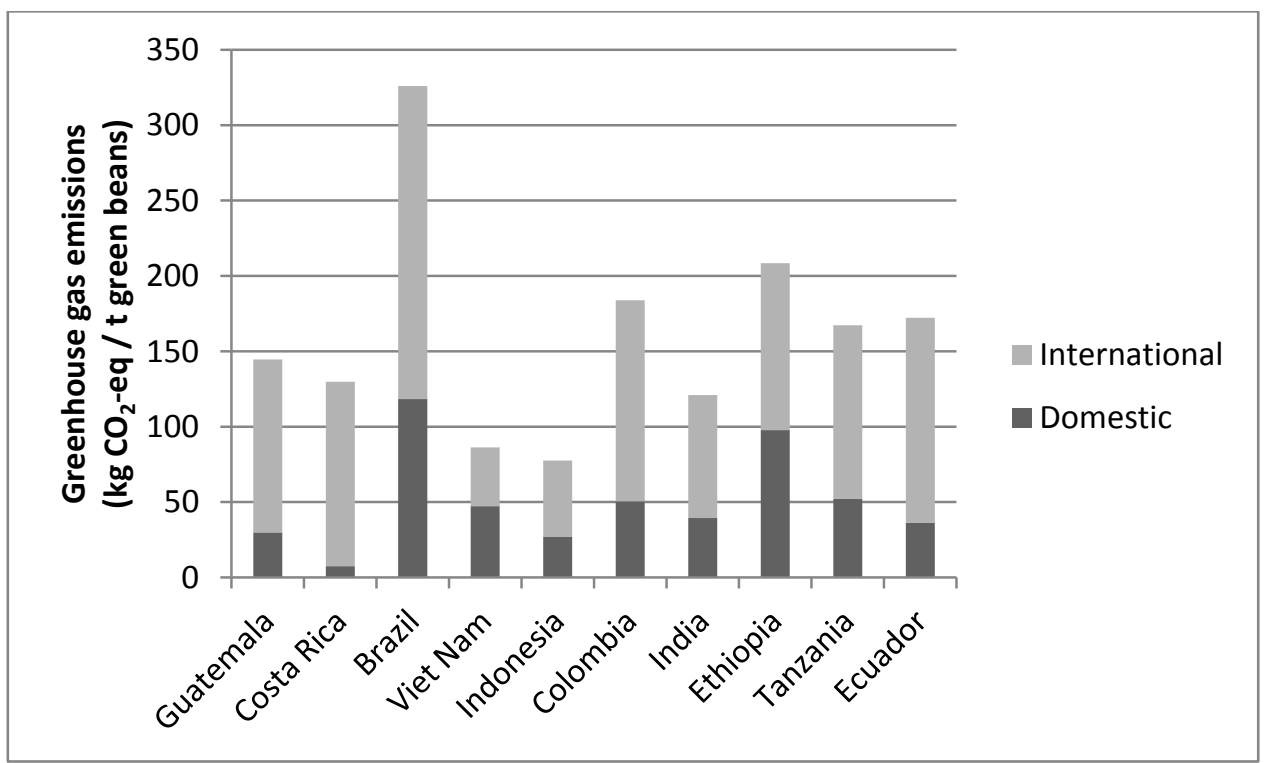


Pre-print version. Please refer to the published version:

Hassard H.A., Couch M.H., Techa-Erawan T., Mclellan B.C.. Product carbon footprint and energy analysis of alternative coffee products in Japan. Journal of Cleaner Production. 73( ), 310-321 (2014) http://dx.doi.org/10.1016/i.jclepro.2014.02.006.

Figure 4: Overall PCF and embodied energy across alternative coffee products and functional units: (a) per serve, (b) per $\mathrm{mL}$ of coffee product, and (c) per gram of roast coffee

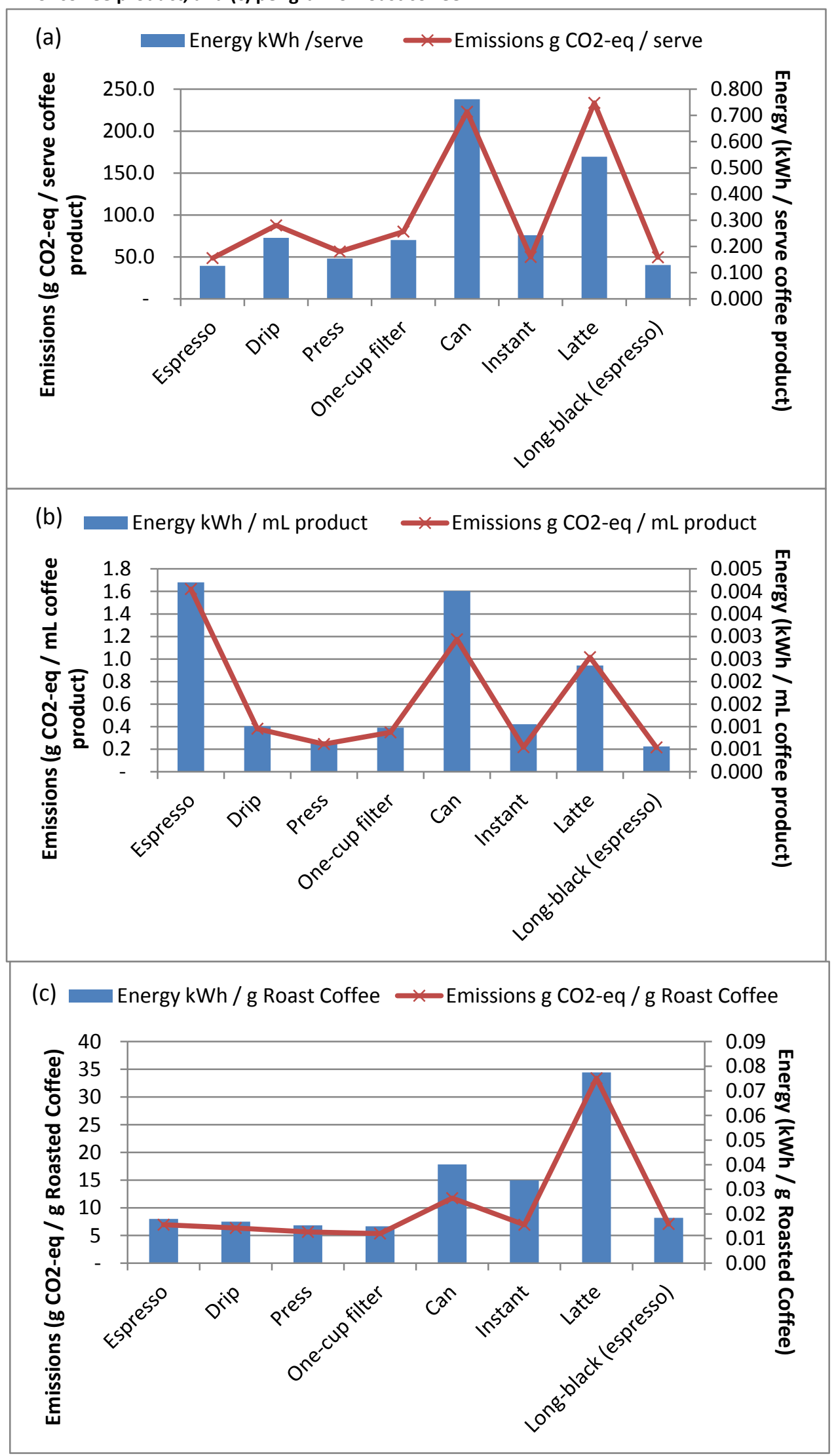


Pre-print version. Please refer to the published version:

Hassard H.A., Couch M.H., Techa-Erawan T., Mclellan B.C.. Product carbon footprint and energy analysis of alternative coffee products in Japan. Journal of Cleaner Production. 73( ), 310-321 (2014) http://dx.doi.org/10.1016/i.jclepro.2014.02.006.

Figure 5: Breakdown by operation for (a) Embodied energy and (b) carbon footprint of alternative coffee products
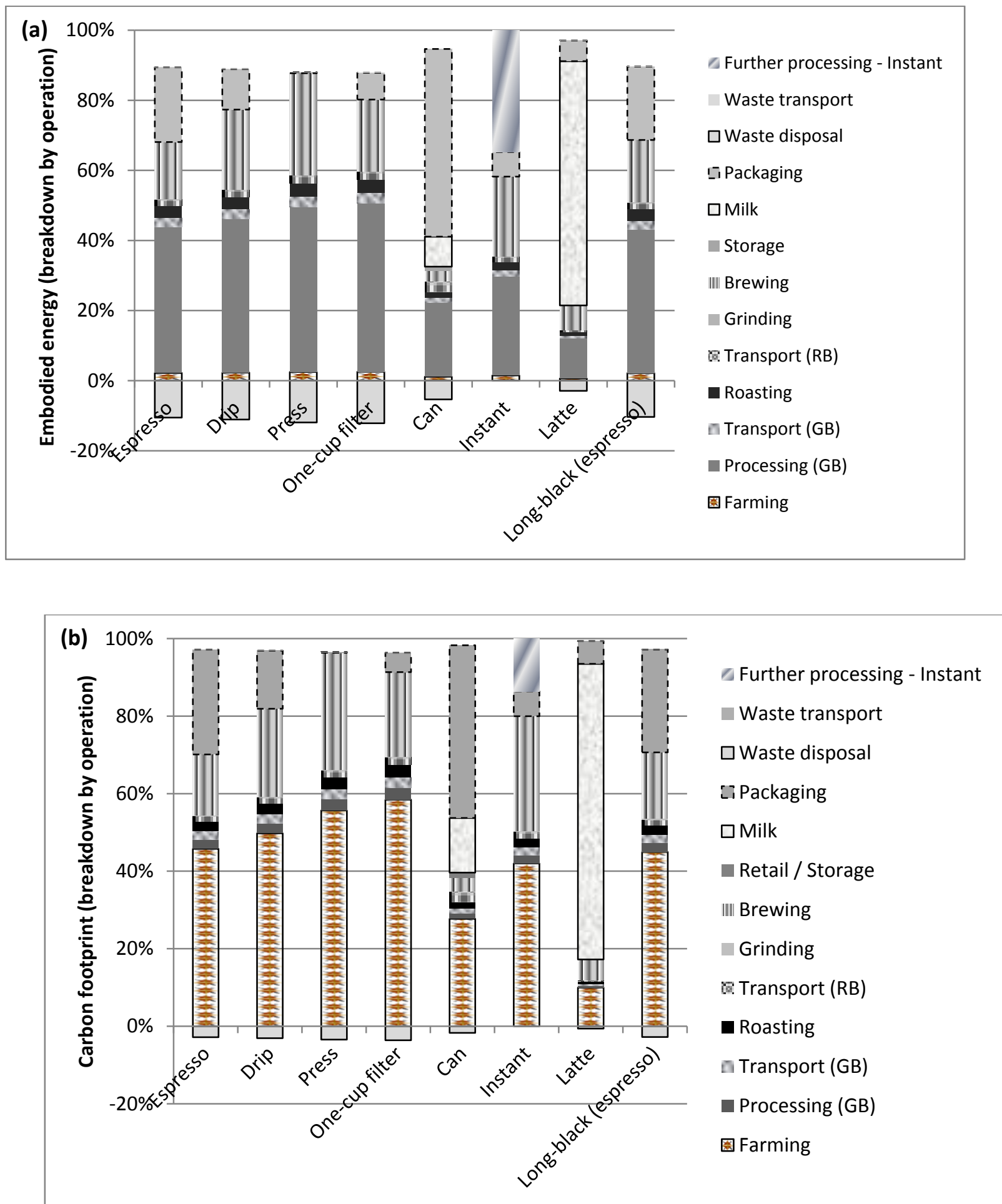
Pre-print version. Please refer to the published version:

Hassard H.A., Couch M.H., Techa-Erawan T., Mclellan B.C.. Product carbon footprint and energy analysis of alternative coffee products in Japan. Journal of Cleaner Production. 73( ), 310-321 (2014) http://dx.doi.org/10.1016/i.jclepro.2014.02.006.

Figure 6: Embodied energy by specific activities for the life cycle of a Latte

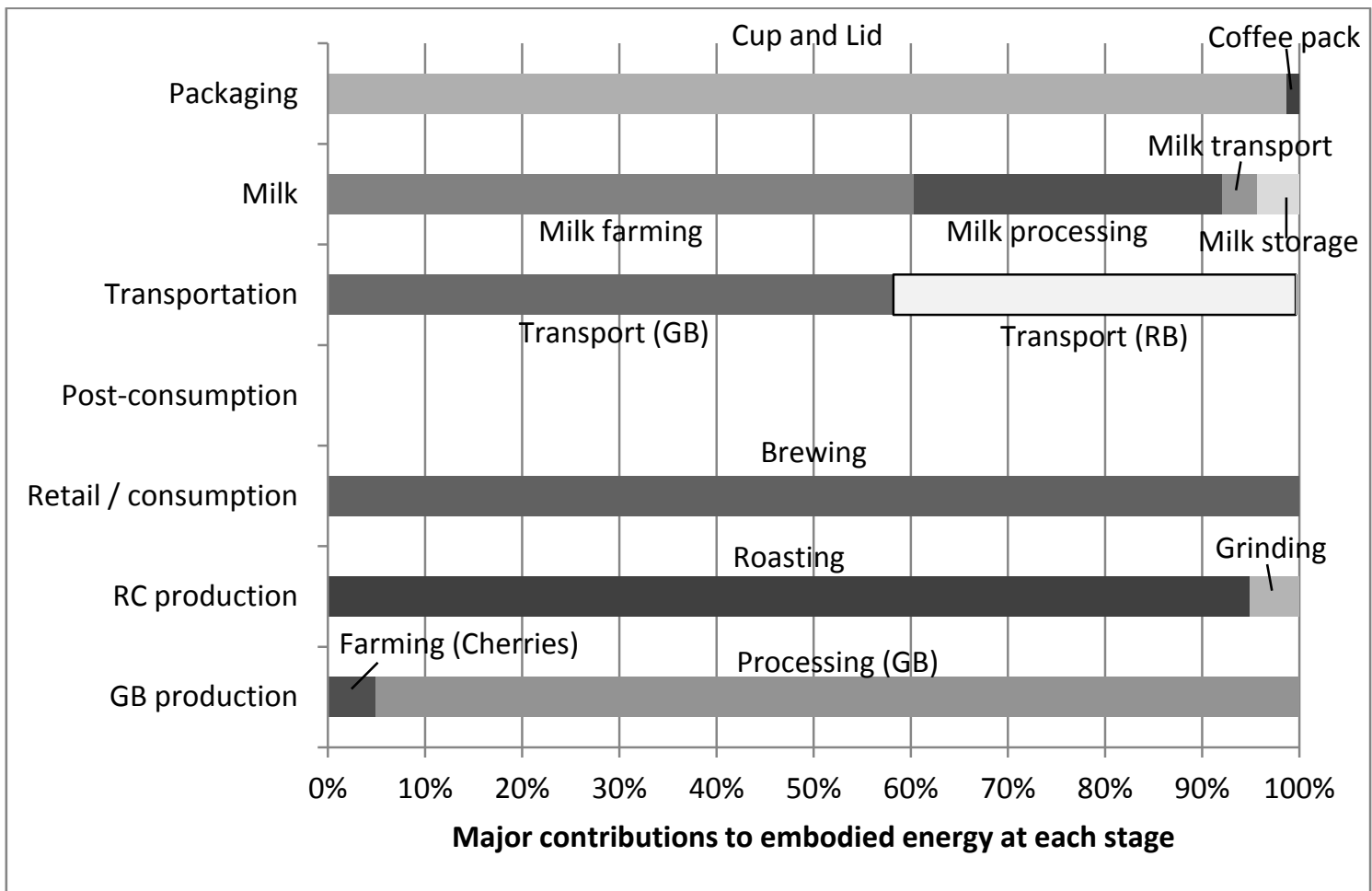

Figure 7: Carbon footprint contribution by specific activities for the life cycle of a Latte

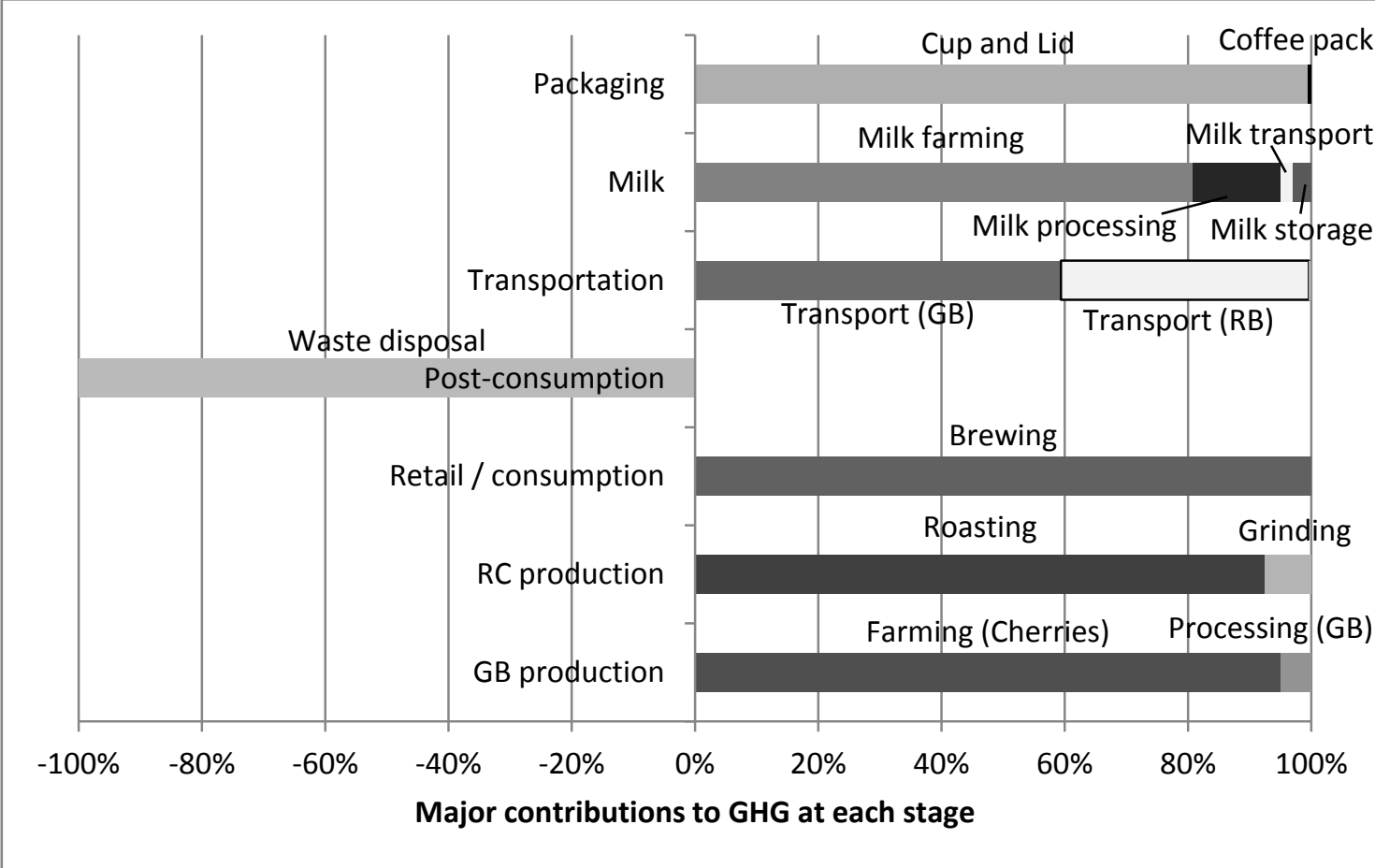


Pre-print version. Please refer to the published version:

Hassard H.A., Couch M.H., Techa-Erawan T., Mclellan B.C.. Product carbon footprint and energy analysis of alternative coffee products in Japan. Journal of Cleaner Production. 73( ), 310-321 (2014) http://dx.doi.org/10.1016/i.jclepro.2014.02.006.

Figure 8: Energy (a) and emissions (b) impacts for the base case PCF compared with carbon storage and post-cultivation footprints
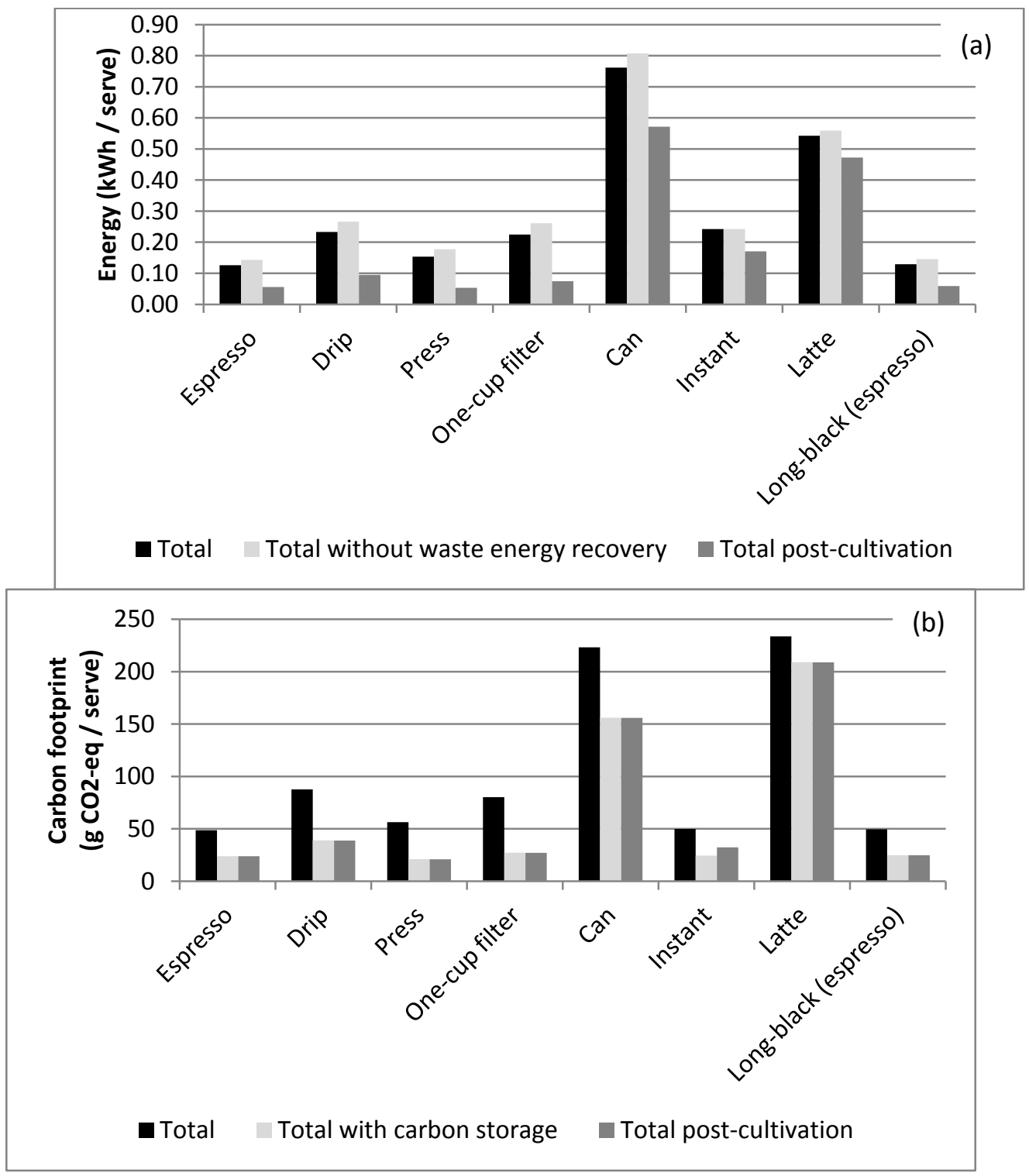
Pre-print version. Please refer to the published version:

Hassard H.A., Couch M.H., Techa-Erawan T., Mclellan B.C.. Product carbon footprint and energy analysis of alternative coffee products in Japan. Journal of Cleaner Production. 73( ), 310-321 (2014) http://dx.doi.org/10.1016/i.jclepro.2014.02.006.

Figure 9: Sensitivity analysis of product carbon footprint to (a) electricity mix , (b) quantity of roast coffee, (c) organic or conventional farming

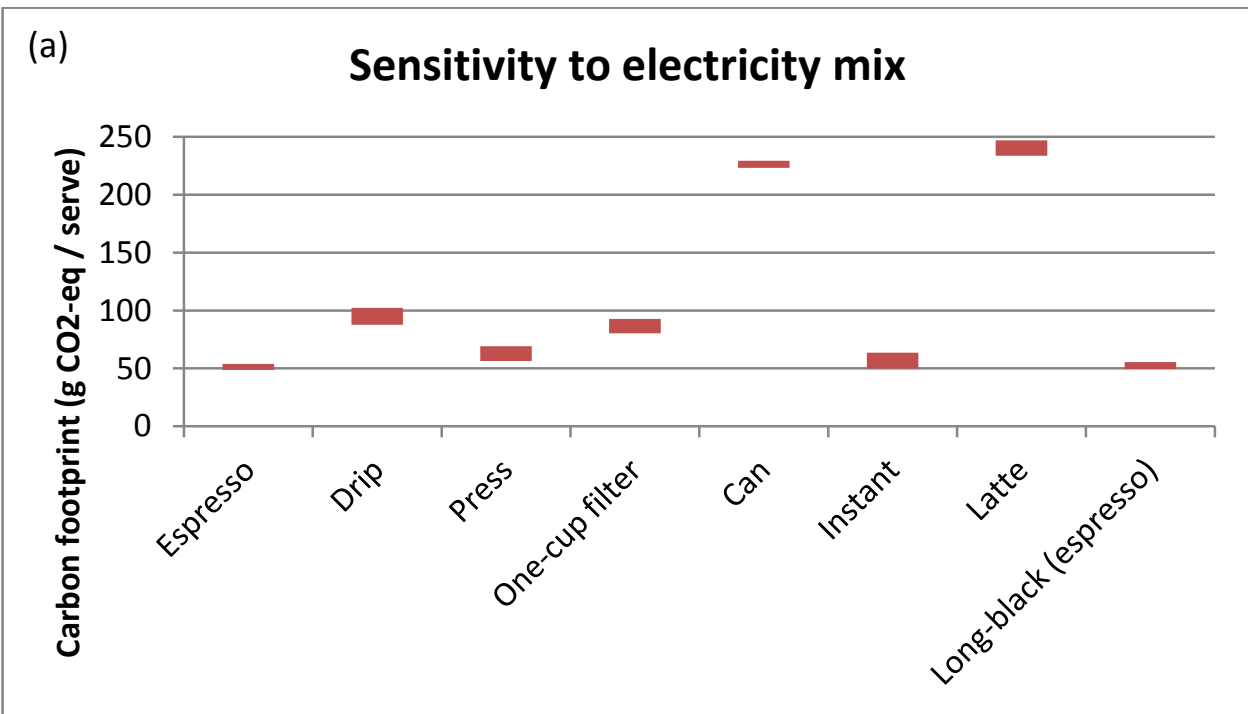

(b)

Sensitivity to quantity of roast coffee

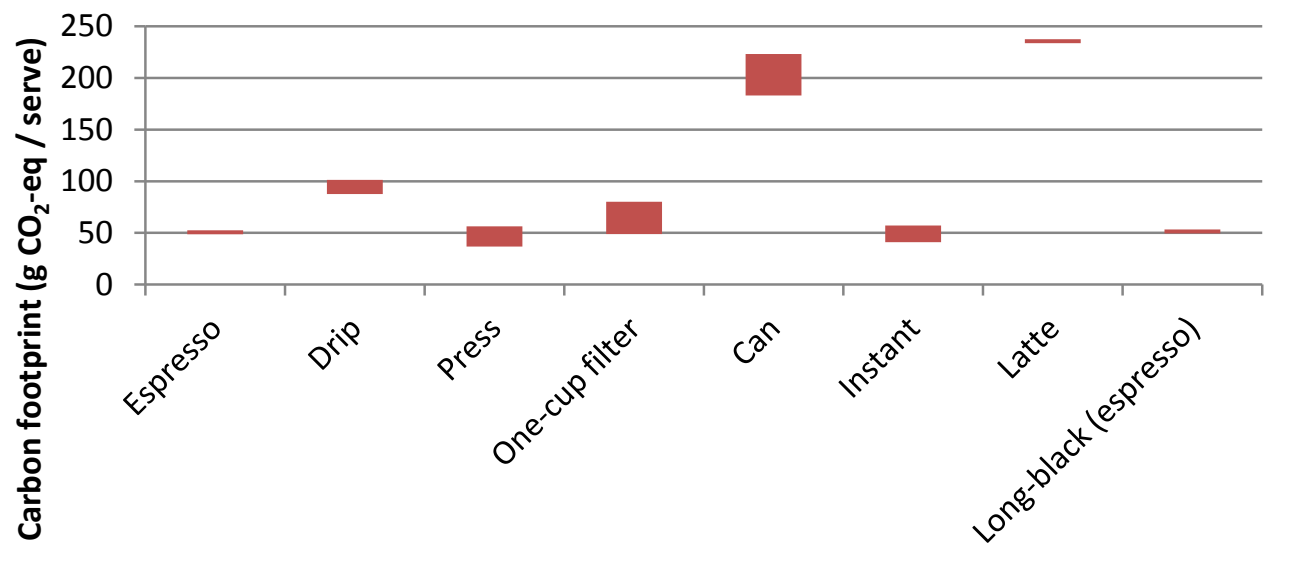

(c)

Organic vs conventional farming

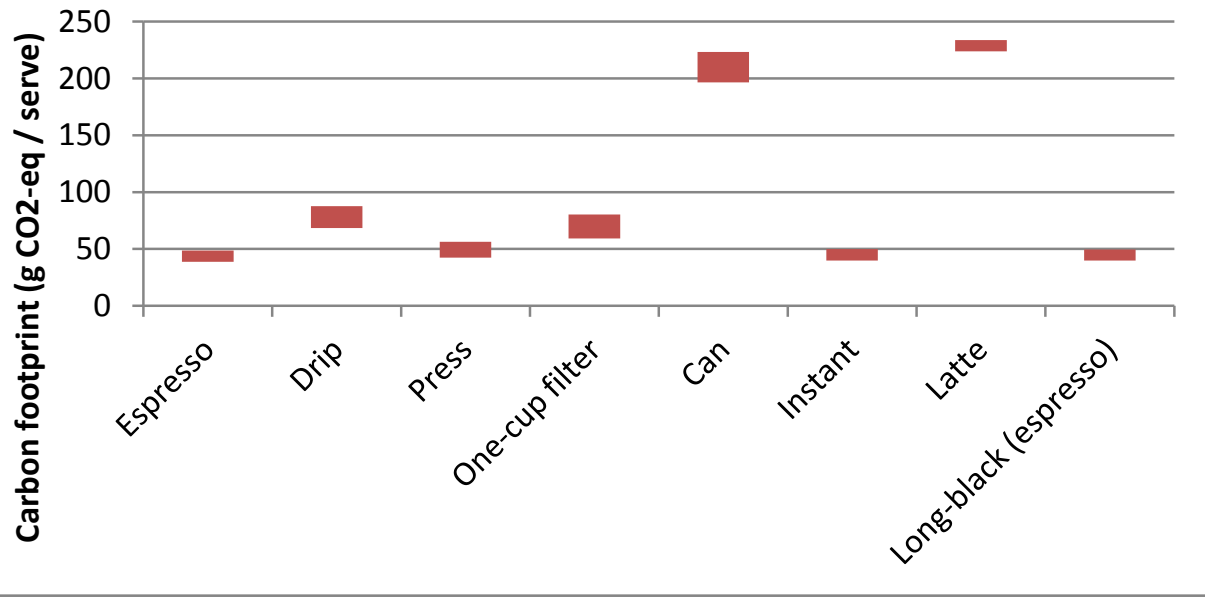


Pre-print version. Please refer to the published version:

Hassard H.A., Couch M.H., Techa-Erawan T., Mclellan B.C.. Product carbon footprint and energy analysis of alternative coffee products in Japan. Journal of Cleaner Production. 73( ), 310-321 (2014) http://dx.doi.org/10.1016/i.jclepro.2014.02.006.

Figure 10: Equivalent cost of abatement of greenhouse gas emissions using coffee discount or bonus schemes

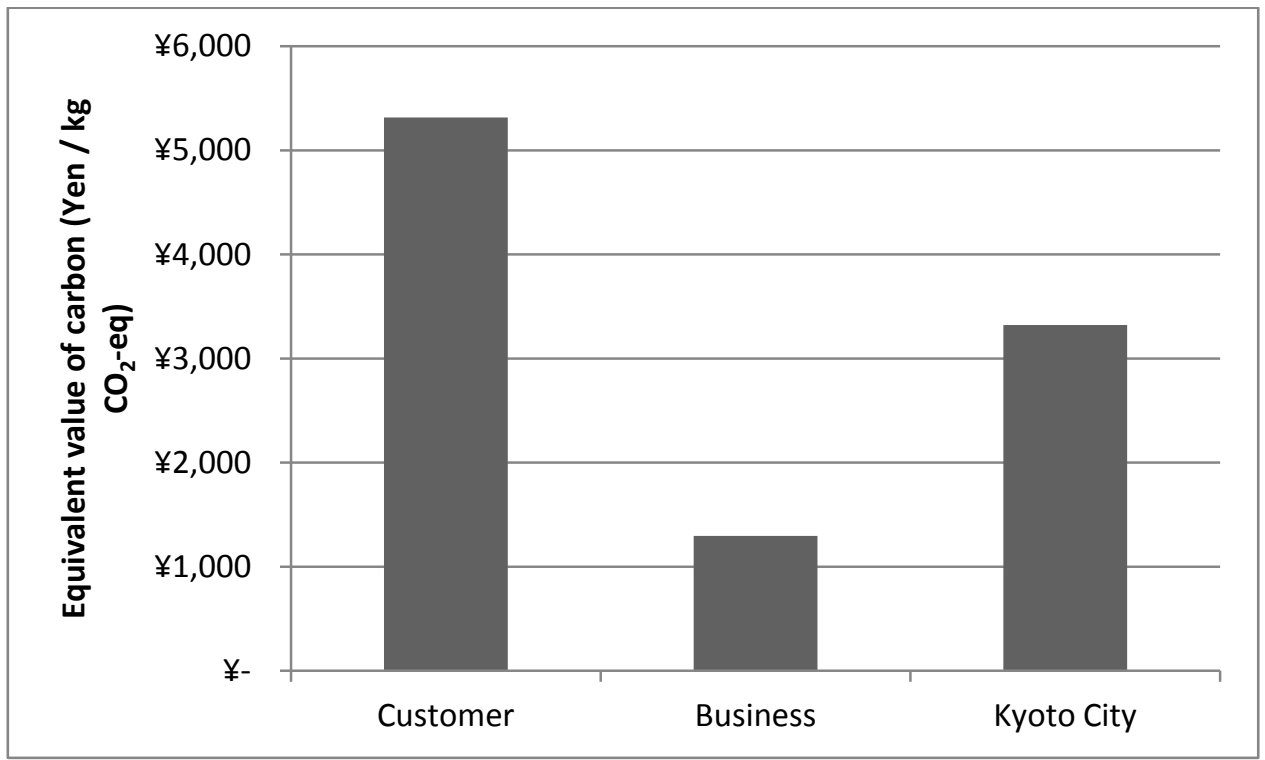

Figure 11: Breakdown of coffee consumption in Japan in 2010 (data source: (AJCA, 2012))

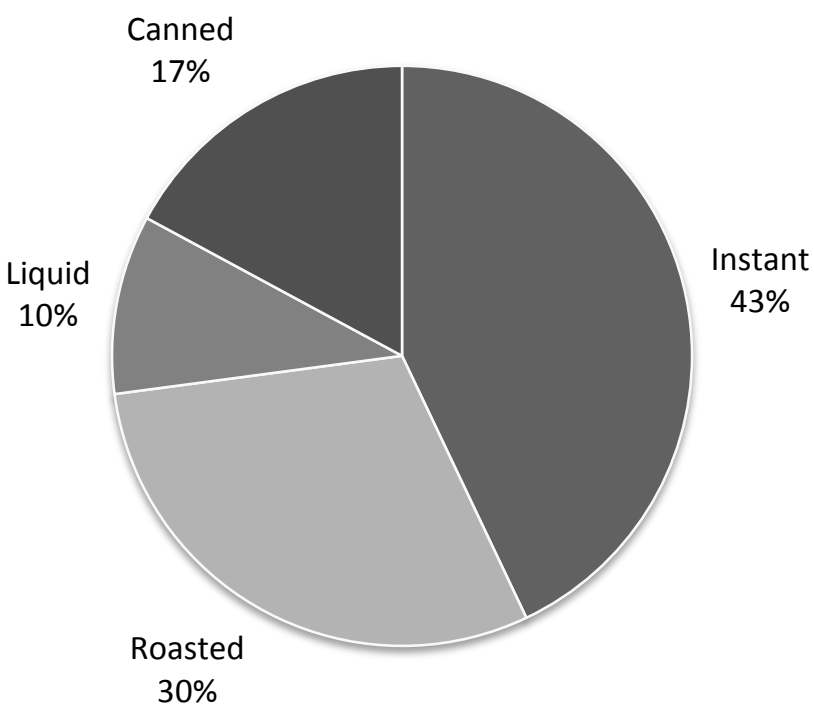

